\title{
1 Processes affecting the efficiency of limestone in passive treatments for AMD: Column experiments
}

4 Francesco G. Offeddu ${ }^{1 *}$, Jordi Cama ${ }^{1}$, Josep M. Soler ${ }^{1}$, Gabriela Dávila ${ }^{1}$, Alastair

\section{McDowell $^{2}$, Teddy Craciunescu ${ }^{3}$ and Ion Tiseanu ${ }^{3}$}

${ }^{I}$ Institute of Environmental Assessment and Water Research (IDAEA), CSIC, Jordi Girona 18-26, 08034

Barcelona, Catalonia, Spain

${ }^{2}$ LBNL Lawrence Berkeley National Laboratory, 1 Cyclotron Road, Berkeley, CA 94720, USA

${ }^{3}$ National Institute for Laser, Plasma and Radiation Physics, Atomistilor Str. 409, P.O. Box. MG-36,

077125 Bucharest-Magurele, Romania

*Corresponding author: francesco.offeddu@idaea.csic.es Phone: +34934006100 ext 1625 Fax: +34 93

JordiCama: jordi.cama@idaea.csic.es; Phone: +34934006100 ext 1627 Fax: +34 932045904

Gabriela Dávila: gabgeo@cid.csic.es; Phone: +34 934006100 ext 1625 Fax: +34 932045904

Alastair McDowell: aamacdowell@lbl.gov; Phone +1 5104864276

TeddyCraciunescu: teddy@infim.ro; Phone: +4 0214574051 Fax: +40214574243 
Offeddu F.G. et al. (2014) Limestone passive treatment

\section{Abstract}

30 Experiments using columns packed with calcite grains (size 1-2 mm) were carried out to

31 study the behavior of passive treatment systems designed to remediate contaminated

32 water from acid mine drainage (AMD). Two types of synthetic acidic solutions $\left(\mathrm{H}_{2} \mathrm{SO}_{4}\right)$

33 were injected in the columns: (1) iron-rich with $\mathrm{Fe}(\mathrm{III})$ at $\mathrm{pH} 2$, and (2) aluminum-rich

34 at $\mathrm{pH} 2$ and 3. Fluid flow was constant during the experiments with Darcy velocities

35 ranging from $6 \times 10^{-4}$ to $1 \times 10^{-3} \mathrm{~L} \mathrm{~m}^{-2} \mathrm{~s}^{-1}$.

37 The columns worked efficiently removing aqueous iron and aluminum as long as calcite 38 dissolved and buffered the solution $\mathrm{pH}$ (increasing $\mathrm{pH}$ and promoting the precipitation 39 of $\mathrm{Fe}(\mathrm{III})-$ or Al-oxyhydroxides). However, Ca released from dissolving calcite, along

40 with the sulfate in solution, led to formation of gypsum coatings on the calcite grain 41 surfaces which eventually prevented calcite dissolution. This passivation process 42 limited the efficiency of the columns. Larger input sulfate concentrations or higher $\mathrm{pH}$ 43 led to shorter passivation times.

45 Characterization of the pore structure and composition by X-ray microtomography 46 (mCT) and X-ray microdiffraction (mXRD) showed the precipitation of gypsum 47 coatings on the calcite grains and secondary oxyhydroxides between the grains. This 48 secondary mineral precipitation favored the formation of preferential flow paths, 49 isolating regions of non-reacted limestone. An improved experimental design (mixing 50 limestone grains and glass beads) minimized the formation of these preferential flow 51 paths. 
Offeddu F.G. et al. (2014) Limestone passive treatment

53 Experimental results have been modeled with the CrunchFlow reactive transport code.

54 Fitting of the results required a decrease in the reactive surface area of calcite, which is 55 consistent with the passivation process.

57 Keywords: Acid Mine Drainage, passive treatment, passivation, clogging, X-ray 58 microtomography

\section{1. Introduction}

62 Acid Mine Drainage (AMD) is defined as the outflow of acidic water from metal or coal 63 mines both in activity or abandoned. It poses an additional risk to the environment by 64 the fact that it frequently contains elevated concentrations of metals (iron, aluminum, 65 manganese, and possibly other heavy metals) and metalloids (of which arsenic is 66 generally of greatest concern) [1,2]. These contaminants can persist in environment

67 during several centuries after interruption of mining activity [3]. The main AMD68 generating mineral is pyrite $\left(\mathrm{FeS}_{2}\right)$ [4-8], according to the following reactions [9]

$70 \mathrm{FeS}_{2}+3.5 \mathrm{O}_{2}(\mathrm{aq})+\mathrm{H}_{2} \mathrm{O} \rightarrow \mathrm{Fe}^{2+}+2 \mathrm{SO}_{4}^{2-}+2 \mathrm{H}^{+}$

$71 \mathrm{Fe}^{2+}+0.25 \mathrm{O}_{2}+\mathrm{H+} \rightleftharpoons \mathrm{Fe}^{3+}+0.5 \mathrm{H}_{2} \mathrm{O}$

$72 \mathrm{Fe}^{3+}+\mathrm{H}_{2} \mathrm{O} \rightleftharpoons \mathrm{Fe}(\mathrm{OH})_{3}+3 \mathrm{H}^{+}$

$74 \mathrm{SO}_{4}{ }^{2-}, \mathrm{Fe}(\mathrm{II})$ and protons are released to solution. $\mathrm{Fe}(\mathrm{II})$ is oxidized to $\mathrm{Fe}(\mathrm{III})$ according

75 to Eq. (2). Fe(III) may precipitate as schwertmannite [10] 
$8 \mathrm{Fe}^{3+}+\mathrm{SO}_{4}^{2-}+14 \mathrm{H}_{2} \mathrm{O} \rightleftharpoons \mathrm{Fe}_{8} \mathrm{O}_{8}(\mathrm{OH})_{6}\left(\mathrm{SO}_{4}\right)+22 \mathrm{H}^{+}$

78 releasing more protons, or as a $\mathrm{Fe}(\mathrm{III})$-hydroxide (ferrihydrite), also releasing protons.

79 But, at $\mathrm{pH}$ lower than $3.5, \mathrm{Fe}(\mathrm{III})$ remains mainly in solution and acts as another 80 oxidizing agent for pyrite according to

84 Since AMD can be highly acidic, it has the capacity to dissolve rocks that are 85 commonly formed by clays and other aluminosilicates. This process releases major rock 86 constituents (e.g. silica, aluminum, iron, sodium, potassium, magnesium, calcium), 87 together with heavy metals, into the environment [1].

89 The main purposes of AMD treatments are retention of metals (precipitation of the 90 contaminant metals) and neutralization of acidity. One of the possible and most 91 common passive treatment systems is the Anoxic Limestone Drain (ALD), or systems 92 derived from it (e.g. Reducing and Alkalinity Producing Systems), characterized by low 93 maintenance needs and low cost [11-17]. ALD uses ditches of buried limestone gravel. 94 Acid water flows through the gravel and limestone dissolves, raising $\mathrm{pH}$ and alkalinity, 95 yielding metal retention as Me-oxyhydroxide precipitates. The efficiency of the ALD 96 systems is however limited because secondary mineral precipitation causes the 97 passivation (armoring) of the limestone grains and clogging of the pores, reducing 98 limestone reactivity and acid neutralization [18-24]. In addition, the presence of 99 aqueous sulfate leads to gypsum precipitation [25-27], which essentially contributes to passivation and affects greatly the efficiency of the treatment systems. 
102 Soler et al. [27] reproduced at the laboratory scale the behavior of ALD systems using 103 column reactors filled with limestone grains. Injecting acid solutions $(\mathrm{pH} 2, \mathrm{HCl}$ and $104 \mathrm{H}_{2} \mathrm{SO}_{4}$ ) with initial concentrations of $\mathrm{Fe}(\mathrm{III})$ ranging from $9.27 \times 10^{-3}$ to $3.61 \times 10^{-2} \mathrm{~mol}$

$105 \mathrm{~L}^{-1}$, it was observed that (1) gypsum coating was responsible for calcite passivation, (2) 106 passivation time in the column was dependent on the initial aqueous sulfate 107 concentration and (3) change in porosity and permeability was due to precipitation of 108 both gypsum and Me-oxyhydroxides. Moreover, once the columns were passivated, X109 ray microtomography was used a posteriori to examine the precipitates responsible for 110 the porosity changes.

111

112 To enhance our knowledge on the loss of calcite reactivity due to grain coating or 113 clogging of porosity initially discussed by Soler et al. [27], this study presents three 114 main innovations:

115

116 The first innovation is that the column experiments were performed using calcite sand 117 and synthetic acid solutions not only containing $\mathrm{Fe}(\mathrm{III})-\mathrm{SO}_{4}{ }^{2-}-\mathrm{H}^{+}$as in Soler et al., [27],

118 but also containing $\mathrm{Al}-\mathrm{SO}_{4}{ }^{2-}-\mathrm{H}^{+}$as major components at $\mathrm{pH}$ 2. Moreover, two 119 experiments were performed at $\mathrm{pH}$ 3. Concentrations of $\mathrm{Fe}(\mathrm{III})$ and $\mathrm{Al}$ ranged from 3.49 $120 \times 10^{-3}$ to $2.60 \times 10^{-2} \mathrm{~mol} \mathrm{~L}^{-1}$ and from $3.60 \times 10^{-3}$ to $3.61 \times 10^{-2} \mathrm{~mol} \mathrm{~L}^{-1}$, respectively, 121 which fall in the range found in AMD [1,28].

123 The second innovation is that in the present study, in order to clarify how the secondary 124 phases precipitate and influence the porosity change, several X-ray microtomography 125 (mCT) measurements were carried out. mCT images were collected at different times 126 during the experiment (before the experiment start and several times till the end of the 
experiment) with the goal of (i) allowing an accurate characterization of the passivation mechanism, which consists of calcite dissolution, consequent surface coating by gypsum precipitates and precipitation of metal oxyhydroxides, and (ii) quantifying

131 decrease in porosity, and the role of gypsum in the calcite passivation mechanism.

133 The overall process is represented by the following reactions:

$$
\begin{aligned}
& \mathrm{CaCO}_{3}+2 \mathrm{H}^{+} \rightarrow \mathrm{Ca}^{2+}+\mathrm{H}_{2} \mathrm{CO}_{3} \\
& \mathrm{Ca}^{2+}+\mathrm{SO}_{4}^{2-}+2 \mathrm{H}_{2} \mathrm{O} \rightarrow \mathrm{CaSO}_{4} \cdot 2 \mathrm{H}_{2} \mathrm{O}(s) \\
& \mathrm{Fe}^{3+}+3 \mathrm{H}_{2} \mathrm{O} \rightarrow \mathrm{Fe}(\mathrm{OH})_{3}(\mathrm{~s})+3 \mathrm{H}^{+} \\
& \mathrm{or} \\
& \mathrm{Al}^{3+}+3 \mathrm{H}_{2} \mathrm{O} \rightarrow \mathrm{Al}(\mathrm{OH})_{3}(\mathrm{~s})+3 \mathrm{H}^{+}
\end{aligned}
$$

137 Reactive transport modeling is a suitable tool for interpreting mathematically the 138 coupled physical and chemical processes occurring in the passive treatment systems.

139 The third innovation is that in this study, the reactive transport code CrunchFlow [29] is 140 used to simulate the processes occurring in the column experiments. As the calcite 141 passivation mechanism (gypsum coating on calcite surface) is not implemented in the 142 code, the following was considered. Assuming that the gypsum coating reduces the 143 calcite reactive surface area, a decrease in calcite area was forced at different times to fit 144 the model results to the experimental data. The resulting simulations allow 145 quantification of the phenomena responsible for the changes in passive treatment 146 efficiency. 
Offeddu F.G. et al. (2014) Limestone passive treatment

\section{2. Materials and methods}

149

150

\subsection{Sample preparation and characterization}

152 Limestone sand was obtained from the Roca Quarry in the Garraf area (Barcelona). This

153 sand was used by Soler et al. [27] and XRD profiles showed only calcite peaks. The

154 grain size used in the experiments was 1-2 $\mathrm{mm}$. To remove calcite microparticles in the column, grains were pre-washed with de-ionized water several times until clear output water was collected. Thereafter grains were dried at $50{ }^{\circ} \mathrm{C}$ for $24 \mathrm{~h}$. The specific surface

157 area of the non-reacted sample was $0.447 \mathrm{~m}^{2} \mathrm{~g}^{-1}$ measured by the BET method using 5158 point $\mathrm{N}_{2}$ adsorption isotherms on a Micromeritics ASAP 2000 surface area analyzer.

\subsection{Column experiments}

161

162 Cylindrical columns were made from transparent polymethyl methacrylate with inner 163 diameters ranging from 1.2 to $2.6 \mathrm{~cm}$ and lengths ranging from 1.1 to $6 \mathrm{~cm}$ (Tables 1 164 and 2). Diameters were sufficiently large so they were about an order of magnitude 165 larger than the limestone grain size. Lengths were sufficiently small so passivation 166 (gypsum coating of the limestone grains) could be achieved in a reasonably short time. 167 All columns included a bed of glass beads ( $2 \mathrm{~mm}$ in diameter) of $3 \mathrm{~mm}$ of thickness at 168 the top and bottom to homogenize the influent and effluent solutions (Fig. 1a). Columns 169 were hand filled with the pre-washed calcite grains. In a few columns, calcite grains 170 were mixed with glass beads (33 wt $\%$ of grains and $67 \mathrm{wt} \%$ of beads) to improve 171 solution circulation (Fig. 1b). Column porosity was calculated from the known calcite 172 mass, volume of the column and calcite density $\left(2.71 \mathrm{~g} \mathrm{~cm}^{-3}\right)$ and also from the acquired 
173 mCT images of the columns using the gray-scale segmentation method. The initial 174 porosity, based on density calculations and mCT measurements, ranged from 40 to 60

$175 \%$ (Tables 1 and 2). Input solutions were injected from the column bottom upwards by a

176 Gilson peristaltic pump under constant flow rate, yielding fluxes of $6 \times 10^{-4}$ and $1 \times 10^{-3} \mathrm{~L}$

$177 \mathrm{~m}^{-2} \mathrm{~s}^{-1}$. Residence time ranged from 1.6 to $3.4 \mathrm{~h}$. The experiments run for $\mathrm{mCT}$

178 measurements (see below) were temporarily stopped at different times in order to

179 acquire the mCT images before the experiment (d0) and after 4,8 and 12 days $(\mathrm{d} 4, \mathrm{~d} 8$

180 and d12). After each image acquisition the experiments were restarted again.

182 After the experiments, epoxy resin was injected in some columns. Once it hardened, the 183 column was cut into slices for further mineralogical inspection by scanning electron 184 microscopy (SEM) and micro X-ray diffraction (mXRD). Most experiments were 185 replicated three times.

\subsection{Solutions}

189 Input solutions were made from adequate amounts of $\mathrm{Fe}_{2}\left(\mathrm{SO}_{4}\right)_{3} \cdot 5 \mathrm{H}_{2} \mathrm{O}$ and $190 \mathrm{Al}_{2}\left(\mathrm{SO}_{4}\right)_{3} \cdot 16 \mathrm{H}_{2} \mathrm{O}$ reagents (pro analysis grade) and Millipore MQ water $(18 \mathrm{M} \Omega \mathrm{cm})$.

191 The solutions $\left(\mathrm{H}_{2} \mathrm{SO}_{4}\right)$ had initial concentrations of $\mathrm{Fe}(\mathrm{III})$ ranging from $3.49 \times 10^{-3}$ to $1922.60 \times 10^{-2} \mathrm{~mol} \mathrm{~L}^{-1}$ and of $\mathrm{Al}$ ranging from $3.60 \times 10^{-3}$ to $3.61 \times 10^{-2} \mathrm{~mol} \mathrm{~L}^{-1}$. Sulfate 193 concentrations ranged from $1.02 \times 10^{-2}$ to $4.39 \times 10^{-2} \mathrm{~mol} \mathrm{~L}^{-1}$ for iron columns and from $1941.04 \times 10^{-2}$ to $5.92 \times 10^{-2} \mathrm{~mol} \mathrm{~L}^{-1}$ for aluminum columns. In most of the experiments 195 solution $\mathrm{pH}$ was 2 and only in two aluminum experiments the $\mathrm{pH}$ was 3. $\mathrm{pH}$ was 196 adjusted by adding concentrated $\mathrm{H}_{2} \mathrm{SO}_{4}$ to the iron sulfate or aluminum sulfate solutions 197 (Tables 1 and 2). 
Offeddu F.G. et al. (2014) Limestone passive treatment

\subsection{Analytical methods}

201 Input and output concentrations of $\mathrm{Fe}, \mathrm{Al}, \mathrm{S}, \mathrm{Mg}, \mathrm{Ca}, \mathrm{Na}$ and $\mathrm{Si}$ were measured by 202 Inductively Coupled Plasma - Atomic Emission Spectrometry (ICP-AES), using a

203 Thermo-Jarrel Ash spectrometer equipped with a CID detector. The detection limits for

$204 \mathrm{Fe}, \mathrm{S}, \mathrm{Mg}, \mathrm{Ca}, \mathrm{Al}$ and Si were $1.8 \times 10^{-7}, 3.5 \times 10^{-6}, 10^{-5}, 5 \times 10^{-6}, 7.5 \times 10^{-7}$ and $7 \times 10^{-7}$

$205 \mathrm{~mol} \mathrm{~L}^{-1}$, respectively. The error associated with ICP-AES measurement was estimated 206 to be around 3\%, based on measurement of different standard solutions in the 207 calibration process. The solution $\mathrm{pH}$ was measured during the experiments with a 208 Thermo Electron Orion $720 \mathrm{~A}+\mathrm{pH}$ meter at room temperature $\left(22 \pm 2{ }^{\circ} \mathrm{C}\right)$ with an error 209 of $\pm 0.02 \mathrm{pH}$ units. The electrode was regularly calibrated with buffer solutions at $\mathrm{pH} 2$

210 and 7. The output solution $\mathrm{pH}$ was continuously measured by placing the electrode in a 211 sealed tube in which the output solution circulated (Fig. 1a). The saturation indexes for 212 calcite and gypsum were calculated at $25{ }^{\circ} \mathrm{C}$ using the PHREEQC code [30] and 213 MINTEQ database [31].

215 Two sets of X-ray microtomography (mCT) images were taken using two different X216 ray sources. The reason was time availability for the instruments. The first set was taken 217 at the 8.3.2 beamline of the Advanced Light Source (ALS, Berkeley, California). 218 Images were taken at X-ray energy of $40 \mathrm{keV}$ using a superbend magnet source and a 219 multilayer monochromator. The columns were mounted on a rotary stage and images 220 were collected every $0.25^{\circ}$ through a full $180^{\circ}$ rotation. Transmitted X-ray light was 221 converted to visible light using a $\mathrm{CdWO}_{4}$ single crystal scintillator, magnified by a 222 Cannon $2 \mathrm{X}$ lens, and imaged on a Cooke PCO 4000 CCD camera with a final pixel size 
of $4.4 \mu \mathrm{m}$. Three exposures of $200 \mathrm{~ms}$ each were averaged together for a total of $600 \mathrm{~ms}$ exposure per image. Nine dark images (with X-ray shutter closed) and 25 open beam images (with sample removed from beam) were taken at the end of the data collection and used for background subtraction and normalization. Raw images were reconstructed using the Octopus commercial software package [32].

A second set of mCT images was taken at the National Institute for Lasers, Plasma and

230 Radiation Physics (NILPRP, Bucharest-Magurele, Romania). The mCT equipment 231 worked with Cone beam CT rapid scan $\left(180^{\circ}+1 / 2\right.$ fan angle), Oblique View Cone

232 Beam. X-ray energy was $225 \mathrm{kVp}$ and a maximum power of $10 / 15 \mathrm{~W}$, using a tungsten

233 filament source. The columns were mounted on a rotary stage, and images were 234 collected every $0.5^{\circ}$. The linear detector, using 1,024 scintillator - photo diode 235 assemblies, yielded 16-bit output digital files that were reconstructed using the 236 VGstudio Max 2.0 software package [33]. All mCT images were taken before and 237 during the experiments at regular time intervals. The segmentation method (separation 238 of gray-scale range values) was applied to quantify porosity using the ImageJ software

239 [34]. This method permits separation and measurement of the pore space between 240 calcite grains and precipitates over the whole image pack.

242 Quantification of precipitated gypsum and oxyhydroxides was carried out manually 243 using the Amira 5.2 3D visualization software [35]. Since acquirement of mCT images 244 is based on the different density of the materials, and the density of Al-hydroxides is 245 very low, it was impossible to obtain mCT images of the Al-compounds in the 246 aluminum columns. Hence, only the mCT images in some of the iron columns were 247 used to characterize the mineral variation with time at different time intervals. Time to 
capture the mCT images was $\sim 2 \mathrm{~h}$. In the mCT images each mineral (calcite, Fe-

249 oxyhydroxides, gypsum, glass beads) has a different gray color according to its density

250 and composition (X-ray absorption coefficient). The pore space is black.

252 In order to identify the mineral phases in the columns, X-ray microdiffraction (mXRD)

253 measurements of several thin sections from the passivated columns were performed at

254 the 12.3.2 beamline, ALS (Berkeley, California). The instrument uses Kirkpatrick-Baez

255 optics to focus the monochromatic X-ray beam delivered by the synchrotron 256 superconducting magnet source down to a size of about $15 \times 2 \mu \mathrm{m}^{2}$ at the sample 257 position. The sample was mounted on a precision XY stage and illuminated with a 8 $258 \operatorname{keV}(\lambda=1.55 \AA)$ monochromatic $\mathrm{X}$-ray radiation at an incidence angle of $10^{\circ}$. Iron $\mathrm{X}$ 259 ray fluorescence signal was also collected using a Si-drift Vortex detector. mXRD 260 patterns were obtained using a MAR133 X-ray CCD detector. The CCD was set to an 261 angle of $2 \theta=40^{\circ}$ at a distance of $119 \mathrm{~mm}$ from the sample. The exposure time per point 262 for the diffraction patterns was $200 \mathrm{~s}$. The signal collection time per point for 263 fluorescence was $0.2 \mathrm{~s}$.

265 Scanning Electron Microscopy (SEM) images were taken on C-coated samples using a 266 Hitachi H-4100FE instrument under a $15-20 \mathrm{kV}$ potential.

\section{$268 \quad 2.5$ Reactive transport modeling}

269

270 One-dimensional simulations of the column experiments were performed using the

271 CrunchFlow reactive transport code [29]. Crunchflow solves numerically the adversion-

272 dispersion-reactions equations 
$273 \quad \frac{\partial\left(\phi C_{i}\right)}{\partial t}=\nabla \cdot\left(\mathbf{D} \nabla C_{i}\right)-\nabla\left(\mathbf{q} C_{i}\right)+R_{i} \quad(i=1,2,3, \ldots, \mathrm{n})$

274 where $\phi$ is porosity, $C_{i}$ is the concentration of component $\mathrm{i}\left(\mathrm{mol} \mathrm{m}{ }^{-3}\right)$, $\mathrm{q}$ is the Darcy

275 velocity $\left(\mathrm{m}^{3} \mathrm{~m}^{-2} \mathrm{~s}^{-1}\right), R_{i}$ is the total reaction rate affecting component $i\left(\mathrm{~mol} \mathrm{~m}^{-3}\right.$ rock s$\left.{ }^{-1}\right)$

276 and $\mathrm{D}$ is the combined dispersion-diffusion coefficient $\left(\mathrm{m}^{2} \mathrm{~s}^{-1}\right)$. The total reaction rate

277 for component $i$ is given by

$278 \quad R_{i}=-\sum_{m} v_{i m} \cdot R_{m}$

279 where $R_{m}$ is the rate of precipitation $\left(\mathrm{R}_{\mathrm{m}}>0\right)$ or dissolution $\left(\mathrm{R}_{\mathrm{m}}<0\right)$ of mineral $m$ per

280 unit volume of rock, and $v_{i m}$ is the number of moles of $i$ per mole of mineral $\mathrm{m}$. Since

281 mineral reactions are described using kinetic rate laws, initial mineral surface areas and

282 several reaction rate parameters have to be supplied by the user as input. In the

283 simulations, the reaction rate laws that have been used are of the form [36]

$284 \quad R_{m}=A_{m} \sum_{\text {terms }} k_{m} a_{H^{+}}^{n}\left(\Omega_{m}-1\right)$

285 where $A_{m}$ is the reactive surface area of the mineral $\left(\mathrm{m}^{2} \mathrm{~m}^{-3}\right), k_{m}$ is the rate constant (mol $286 \mathrm{~m}^{-2} \mathrm{~s}^{-1}$ ) and $a_{H^{+}}^{n}$ is a term describing the dependence of the rate on $\mathrm{pH}$. The term in 287 brackets stands for the effect of solution saturation state.

$\Omega_{\mathrm{m}}=I A P_{m} / K_{m}$

290 where $I A P_{m}$ is the ionic activity product of the solution with respect to the mineral and

$291 K_{m}$ is the equilibrium constant for the dissolution reaction (ionic activity product at equilibrium). If $\Omega_{\mathrm{m}}<1$, the solution is undersaturated and the reaction is of dissolution; if $\Omega_{\mathrm{m}}>1$, the solution is supersaturated and the reaction is of precipitation; at equilibrium $\Omega_{\mathrm{m}}=1$ and $R_{m}=0$.

296 Changes in mineral surface area $A_{m}\left(\mathrm{~m}^{2} / \mathrm{m}^{3}\right.$ bulk) due to reaction are calculated according to 
where $\phi_{m}$ is mineral volume fraction. The inclusion of a $2 / 3$ dependence on porosity is chiefly to ensure that as the porosity goes to 0 , so too does the mineral surface area available for reaction.

303 This formulation is used primarily for primary minerals (that is, minerals with initial volume fractions $>0$ ). For secondary minerals which precipitate, the value of the initial bulk surface area specified is used as long as precipitation occurs-if this phase later dissolves, the above formulation is used, but with an arbitrary "initial volume fraction" of 0.01 .

\section{Results and Discussion}

310 Tables 1 and 2 show the experimental conditions of the aluminum and iron column

311 experiments, respectively. The experiments lasted from 142 to $4774 \mathrm{~h}$ depending on

312 their geochemical evolution.

\subsection{Aluminum columns}

316 Fig. 2a shows variation of the output concentrations of $\mathrm{Ca}, \mathrm{SO}_{4}$ and $\mathrm{Al}$ and output $\mathrm{pH}$ in 317 a representative $\mathrm{Al}$ column experiment (experiment 16 in Table 1). Initial pH was 2 and 318 initial $\mathrm{Al}$ and sulfate concentrations were $2.22 \times 10^{-2} \mathrm{~mol} \mathrm{~L}^{-1}$ and $3.75 \times 10^{-2} \mathrm{~mol} \mathrm{~L}^{-1}$, 319 respectively. As the solution reacted with calcite, the output $\mathrm{pH}$ increased to $\mathrm{pH}$ between 6 and 7.5 (for $\sim 260$ h) and dissolved Al was completely depleted. The 
321 concentration of $\mathrm{Ca}$ raised to $\sim 1.6 \times 10^{-2} \mathrm{~mol} \mathrm{~L}^{-1}$ and the output concentration of sulfate

322 decreased to $\sim 1.6 \times 10^{-2} \mathrm{~mol} \mathrm{~L}^{-1}$. Therefore, at this stage (Fig. 2a) the calcite-filled

323 column was acting as expected, removing Al from solution, decreasing sulfate

324 concentration and neutralizing acidity. PHREEQC calculations showed that the output

325 solution was undersaturated with respect to calcite, but supersaturated with respect to

326 Al-hydroxide (gibbsite $\left(\mathrm{Al}(\mathrm{OH})_{3}\right)$ and gypsum $\left(\mathrm{CaSO}_{4} \cdot 2 \mathrm{H}_{2} \mathrm{O}\right)$. Both gypsum and

327 gibssite were identified by $\mathrm{mXRD}$, indicating that both phases precipitate under these

328 conditions. After $260 \mathrm{~h}$ (stage II), the output $\mathrm{pH}$ and the output Ca concentration

329 gradually decreased to approach a nearly constant value of $\sim 4$ and $\sim 8.0 \times 10^{-3} \mathrm{~mol} \mathrm{~L}^{-1}$,

330 respectively, until the end of the experiment (Fig. 2a). Output concentration of $\mathrm{SO}_{4}$ and

331 Al increased up to the input concentrations. Therefore, this behavior suggests that

332 calcite dissolution diminished likely due to gypsum precipitation on the calcite grain

333 surfaces (armoring or coating effect), limiting, but not totally avoiding, the buffer

334 capacity of calcite. Precipitation of gypsum and Al-oxyhydroxide (gibbsite) was

335 observed (Fig. 3a, c, and e).

\subsection{Iron columns}

339 The variation in the $\mathrm{Fe}$ concentration in the $\mathrm{Fe}(\mathrm{III})$ columns was similar to that of the $\mathrm{Al}$

340 column experiments. Fig. $2 \mathrm{~b}$ depicts the variation of the output concentration of $\mathrm{Ca}, \mathrm{Fe}$,

$341 \mathrm{SO}_{4}$ and $\mathrm{pH}$. Dissolution of calcite increased the output $\mathrm{pH}(\sim 6)$ and the Ca release (up

342 to $2.27 \times 10^{-2} \mathrm{~mol} \mathrm{~L}^{-1}$ ). Precipitation of gypsum and Fe-oxyhydroxide (goethite) was

343 clearly observed and identified (Fig. 3b, d and f). After 350 h, the output pH sharply

344 dropped to $\sim 2$, the concentration of total $\mathrm{Fe}$ increased to the initial level, and $\mathrm{Ca}$

345 decreased to $5.4 \times 10^{-3} \mathrm{~mol} \mathrm{~L}^{-1} . \mathrm{SO}_{4}$ concentration was higher than the initial one. This 
346 variation suggests that calcite was losing reactivity and the precipitated gypsum was

347 dissolving. However, after ca. $750 \mathrm{~h}$, the output $\mathrm{pH}$ and $\mathrm{Ca}$ increased back up to 6 and

$3482.1 \times 10^{-2} \mathrm{~mol} \mathrm{~L}^{-1}$, respectively, the total $\mathrm{SO}_{4}$ decreased to $\sim 1.6 \times 10^{-2} \mathrm{~mol} \mathrm{~L}^{-1}$, and iron

349 was depleted. This behavior indicated that calcite dissolution resumed to yield gypsum

350 and goethite precipitation. Finally, after $\sim 1550 \mathrm{~h}$ a second, perhaps definitive calcite

351 passivation occurred before the end of the experiment.

\subsection{Passivation and clogging processes}

355 The dissolution of calcite in the experiments released $\mathrm{Ca}$ from the limestone grains, 356 which combined with the $\mathrm{SO}_{4}$ in solution and caused precipitation of gypsum on the 357 calcite surfaces. Gypsum coating of the grains eventually prevented access of solutes to 358 the grain surfaces and calcite dissolution (passivation). As a result of passivation, output $359 \mathrm{pH}$ dropped to values close to the input value, metal retention stopped and $\mathrm{SO}_{4}$ 360 concentrations increased to levels close to the input value (or even higher if gypsum 361 dissolved). The time required to reach passivation (passivation time, $\mathrm{t}_{\mathrm{pass}}$ ), depended on 362 the input concentration of $\mathrm{SO}_{4}$, which correlated with metal concentration $(\mathrm{Fe}$ and $\mathrm{Al}$ 363 were added as sulfate salts). It was considered that columns were passivated when $\mathrm{pH}$ 364 remained at values near that of the input solution for 5 consecutive days.

366 Figures $4 \mathrm{a}$ and $4 \mathrm{c}$ show plots of $\mathrm{t}_{\text {pass }}$ normalized to residence time tau (column length 367 divided by initial linear velocity) vs. initial $\mathrm{SO}_{4}$ concentration. The tendency observed 368 in both $\mathrm{Fe}$ and $\mathrm{Al}$ columns is that $\mathrm{t}_{\mathrm{pass}}$ increased when decreasing the input sulfate (and 369 metal) concentrations (Fig. 4a, c). This trend was already observed by Soler et al. [27] 370 in Fe column experiments using two different limestone grain sizes (1-2 and 2-5 mm). 
Offeddu F.G. et al. (2014) Limestone passive treatment

371 In the $\mathrm{Al}$ column experiments, $\mathrm{t}_{\mathrm{pass}}$ also tends to be higher in the experiments run at $\mathrm{pH}$

3723 than in those at $\mathrm{pH} 2$.

373

374 Calcite dissolution also caused an increase in $\mathrm{pH}$ from 2 to $\sim 6-7$ (proton consumption),

375 resulting in supersaturation of the solutions with respect to Fe- or Al-oxyhydroxides.

376 Clogging of the pore space was observed in some experiments (flow stopped due to the

377 decrease in permeability). Time required to clog the columns was larger than

378 passivation times (arrows in Figs. 4a, b), indicating that when efficiency was better (i.e.

379 the columns lasted longer), clogging took place before any passivation could be

380 observed. Clogging was caused by the precipitation of metal-oxyhydroxides between

381 the grains.

383 To check reproducibility of results most experiments were repeated at least 3 times.

384 Reproducibility was little, as significant variability in $t_{\text {pass }} /$ tau was observed (Tables 1

385 and 2). For example, results from $\mathrm{Fe}$ experiments with initial $\mathrm{SO}_{4}$ concentration of

$386 \sim 1.0 \times 10^{-2} \mathrm{~mol} \mathrm{~L}^{-1}$ show that time to reach clogging ranged from $\sim 700$ to $\sim 2600 \mathrm{t} / \tau$ (Fig.

387 4a). Another factor to take into consideration was the occurrence of temporary calcite

388 passivation events and subsequent reactivations. Soler et al. [27] reported them to occur

389 only in columns with $\mathrm{Fe}(\mathrm{III})-\mathrm{Cl}-\mathrm{H}^{+}$solutions and not in $\mathrm{Fe}(\mathrm{III})-\mathrm{SO}_{4}-\mathrm{H}^{+}$solutions. The

390 authors argued that in the sulfate solutions the strong attachment of gypsum onto calcite

391 surfaces could prevent the reactivations. However, temporary passivation and

392 reactivation has now been observed in sulfate solutions. Removal of fine grained

393 precipitates from calcite surfaces could be the mechanism causing these reactivations. 
395 Figures $4 \mathrm{~b}$ and $4 \mathrm{~d}$ show the amount of metal retained (calculated as the product between

396 input metal concentration in $\mathrm{mg} \mathrm{L}^{-1}$, flow rate in $\mathrm{L} \mathrm{h}^{-1}$ and $\mathrm{t}_{\text {pass }}$ in $\mathrm{h}$ ), normalized to the

397 initial mass of calcite, vs. sulfate concentration of the input solution. The figures show

398 no clear trend. Results plotting on the left correspond to experiments with small input

399 sulfate concentrations which gave large $t_{\text {pass }}$ values. Results plotting on the right

400 correspond to experiments with larger input concentration which gave lower $t_{\text {pass }}$ values

401 (Figs. 4a and 4c). This opposite distribution of input concentrations and $t_{\text {pass }}$ can explain

402 the lack of a trend in metal retention versus input concentration.

403

404 mCT examinations of column experiment $\mathrm{H}$ allowed detailed identification of the 405 mineralogical and porosity changes (Fig. 5). mCT examinations were performed at 406 different times (Fig. 6, Table 2): before injection (d0) and after 4, 8 and 12 days. The 407 four mCT images in Fig. 6 show the same section close to the column inlet. Slight 408 variations in the position of the grains with time were due to sample compaction during 409 the experiment. Initially only calcite grains were present (light gray), separated from 410 each other by pore space (dark areas). After $\sim 90 \mathrm{~h}(\mathrm{~d} 4)$ some of the calcite grains were 411 coated by a thin gypsum layer (dark gray) and a whitish phase (goethite) was filling the 412 pore space. Both gypsum and goethite were identified by mXRD. At d(8) and d(12) the 413 gypsum coatings grew and goethite content increased. After 12 days the column was 414 passivated and the experiment was finished. Other $\mathrm{mCT}$ sections along the passivated 415 column showed that in some portions of the column calcite grains did not react with the 416 solution (Fig. 7). At the inlet (bottom) of the column a noticeable presence of goethite 417 filling the pore space and gypsum coatings on grain surfaces is observed. In the lower 418 middle image (LM) approximately $75 \%$ of the grains reacted, leaving some non-reacted 419 grains visible on the left side. In the upper middle section (UM) the fraction of reacted 
420 grains diminished and at the top only $\sim 50 \%$ reacted: a clear separation between reacted

421 and non-reacted regions is readily observed. Formation of preferential paths in the 422 columns was observed in most of the experiments and was more evident in the upper 423 parts of the columns (closer to the outlet).

\subsection{Porosity variation}

426

427 The mCT images showed that precipitation of Me-oxyhydroxides and gypsum caused a 428 decrease in porosity. Once the injected solution reacted with the calcite grains, a 429 reaction front advanced upwards. Fig. 8 shows the porosity variation with time along 430 column $\mathrm{H}$. The black and grey lines represent initial and final porosity, respectively. 431 The two lines in between correspond to the porosity along the column at 4 and 8 days. 432 The lines represent the pore-space area per section area (\%) with an error of $2 \%$ (the 433 sum of calcite, porosity and precipitates areas ranged from $98 \%$ to $102 \%$ ). It is inferred 434 that the initial porosity fluctuates along the column within a difference of $\pm 5 \%$ with 435 respect to the mean porosity value $(45 \%)$ because grain distribution varies along the 436 column. After 4 days of constant injection, a porosity decrease occurs only in the low 437 middle part of the column. After 8 days, a porosity decrease is more evident in the low 438 middle part, although a slight decrease is already observable in the upper part. 439 Thereafter, until full passivation (12 days; grey line), porosity decreases all along the 440 column, being still more evident in the lower middle part $(25 \%)$ than in the upper 441 middle part $(10 \%)$. The final average porosity along the column is $31 \%$. 
Offeddu F.G. et al. (2014) Limestone passive treatment

443 Formation of preferential flow paths, especially in the upper part of the column (Fig. 7),

444 caused isolation of some portions where calcite grains did not react, limiting the barrier

445 efficiency.

446

447 The contribution of gypsum and goethite precipitates to porosity decrease was 448 calculated using the mCT image segmentation method (Fig. 9). After 12 days, 449 precipitation of goethite and gypsum contributed, respectively, $\sim 15 \%$ and $\sim 5 \%$ of 450 porosity decrease from the inlet to the middle of the column. In the upper half, 451 contributions of each phase diminished to 5 to $10 \%$ and 1 to $2 \%$, respectively (Fig. 9).

452 Variation with time of each phase shows that the reaction front progressed upwards, 453 indicating that precipitation of goethite and gypsum was simultaneous (driven by calcite 454 dissolution) and initiated at the inlet where precipitates were more abundant.

456 In order to avoid preferential flow paths, two longer columns $(6 \mathrm{~cm}$ of length and 2.6

$457 \mathrm{~cm}$ in diameter) packed with a homogeneous mixture of glass beads ( $2 \mathrm{~mm}$ in diameter; $45867 \mathrm{wt} \%)$ and calcite grains (1-2 $\mathrm{mm} ; 33 \mathrm{wt} \%)$ were run in an iron-rich solution (Table 459 2). Use of glass beads improves solution circulation through the column. Variation of 460 the output $\mathrm{pH}$ and output $\mathrm{Fe}, \mathrm{SO}_{4}$ and $\mathrm{Ca}$ concentrations is shown in Fig. 10. It is 461 observed that full column passivation (output $\mathrm{pH}$ drop to initial value and iron increase) 462 was achieved after a longer time compared to that in calcite filled columns (e.g. see Fig $4634)$.

465 The mCT images before reaction show regular distribution of calcite grains and beads 466 along the columns (Fig. 11). In fact, formation of preferential flow paths was 467 significantly prevented (only a little unreacted region was observed; Fig. 11). Duration 
468 of the bead-filled experiments was longer before full passivation was achieved and 469 reproducibility was improved (Table 2 and Figs. 4 a and b). The longer period of 470 activity originated a larger and homogenous porosity decrease along the column (Fig. 471 12). Overall, using this column design, the performance of the system was improved. 472 This result is in accordance with those reported by Caraballo et al. [37] and Rötting et 473 al. [38], who showed that addition of inert material in the limestone treatment systems 474 enhances the efficiency of the systems.

475

3.5 Reactive transport modeling of the columns

477

$478 \quad$ 3.5.1 Model parameters

479

480 Model parameters correspond to those of column experiment $\mathrm{H}$. The length of the one481 dimensional domain was $1.2 \mathrm{~cm}$ (the length of the column). Grid spacing was $0.6 \mathrm{~mm}$. 482 Calcite was the only initial mineral, and the secondary minerals that were taken into 483 account were goethite and gypsum (Table 3). Initial porosity of the column and initial 484 volume fraction of calcite were 0.494 and 0.506 , respectively. The initial surface area of 485 calcite $\left(20 \mathrm{~m}^{2} \mathrm{~m}^{-3}\right)$ was adjusted to fit the model to the experimental results. It has to be 486 noted that this area is much smaller than either the geometric surface area of the 487 limestone assuming spherical grains (ca. $2000 \mathrm{~m}^{2} \mathrm{~m}^{-3}$ ) or the area calculated from the 488 BET measurements (ca. $6 \times 10^{5} \mathrm{~m}^{2} \mathrm{~m}^{-3}$ ). An explanation for the small value could be 489 given by the transport (diffusion) control of the net dissolution reactions under acidic $490 \mathrm{pH}$ (e.g. [39]). The resulting small net dissolution rates are implemented in the model 491 through a small surface area term (see eq. 12). Goethite and gypsum surface areas were 492 also adjusted to reproduce the observed experimental data (Table 3). The composition 
493 of the injected water (input solution) was the same as the experimental composition of

494 the input solution $\left(1.74 \times 10^{-2} \mathrm{~mol} \mathrm{~L}^{-1}\right.$ of $\mathrm{Fe}(\mathrm{III}), 3.11 \times 10^{-2} \mathrm{~mol} \mathrm{~L}^{-1}$ of $\mathrm{SO}_{4}$ and $\left.\mathrm{pH} 2\right)$.

495 The composition of the initial water in the column was at equilibrium with calcite and

496 atmospheric $\mathrm{CO}_{2}$ (Table 3). The dispersivity was considered to be equal to grid spacing.

497 Darcy velocity was calculated from the constant flow rate used in the experiments 498 (Table 3).

500 Three minerals and 23 species in solution were taken into account in the calculations.

501 The equilibrium constants for the three mineral reactions are given in Table 4. All the 502 chemical equilibria in solution are listed in Table 5. All the equilibrium constants at 25

$503{ }^{\circ} \mathrm{C}$ were taken from the database included in CrunchFlow, which is based on the EQ3/6

504 database [40]. The kinetic rate laws used in the present study were obtained from [41].

505 Rate parameters for the minerals considered in the calculations are shown in Table 6.

$507 \quad 3.5 .2$ Results

509 As passivation is controlled by gypsum coating on calcite surfaces, calcite reactivity 510 should diminish as a consequence of the loss of calcite reactive surface area. The initial 511 calcite surface area was adjusted to $20 \mathrm{~m}^{2}$ mineral $\mathrm{m}^{-3}$ rock. The initial surface area for 512 gypsum and goethite were also fitted to the initial experimental results. During the 513 course of the simulation, the calcite surface area was decreased stepwise at two different 514 times. After $230 \mathrm{~h}$, the value was reduced to $10 \mathrm{~m}^{2} / \mathrm{m}^{3}$; after $300 \mathrm{~h}$ it was reduced to 0.1

$515 \mathrm{~m}^{2} / \mathrm{m}^{3}$ (Fig. 13). The reactive surface areas of goethite and gypsum were assumed 516 constant during the experiment. This is a model simplification, since areas should 517 increase with precipitation. But even with this underestimation of gypsum and goethite 
518 reactivity it was necessary to reduce the calcite surface area to match the experimental

519 results (smaller $\mathrm{Ca}$ concentrations due to less dissolution of calcite and larger $\mathrm{SO}_{4}$ and

520 Fe concentrations due to less precipitation of secondary gypsum and goethite). This

521 simple model (stepwise reduction of calcite surface area) shows that the experimental

522 results are consistent with a reduction of calcite reactivity induced by the precipitation

523 of gypsum.

525 4. Summary and conclusions

527 Factors affecting the efficiency of limestone in passive treatment systems for AMD

528 were studied using centimetric-scale columns packed with crushed limestone. In these

529 systems, calcite passivation by gypsum coating is an important limitation to the

530 limestone buffer capacity, and the main factors for controlling passivation time were the

531 initial sulfate concentration and $\mathrm{pH}$. A decrease in sulfate concentration and the use of

532 low flow rate enhance the column passivation time. In those experiments run with

533 higher $\mathrm{pH}$ passivation time also improved.

535 Metal retention does not show the same trends as passivation time: there is little 536 sensitivity of metal retained on initial sulfate (and metal) concentration due to the 537 negative correlation between initial concentration and passivation time.

538

539 Another limitation for the treatment efficiency is the formation of preferential flow 540 paths and column clogging. These complementary phenomena are caused by the 541 precipitation of iron or aluminum oxyhydroxides which impede homogeneous 542 circulation of the solutions through the columns. To improve the efficiency in the 
Offeddu F.G. et al. (2014) Limestone passive treatment

543 passive treatment, mixtures of calcite grains and glass beads were used to pack the

544 columns. The addition of an inert substrate clearly improves the efficiency.

546 mCT images and mXRD measurements were used to determine how gypsum coating

547 and metal-oxyhydroxide precipitation occurred and to quantify porosity variation along

548 the columns. It was observed that porosity decreased progressively with time. Gypsum

549 coating contributed $5 \%$ in porosity reduction, whereas goethite contribution was $\sim 15 \%$.

550 Gypsum and goethite precipitation was simultaneous.

551

552 A good match between experimental results and reactive transport simulations was

553 achieved. Fitting of the results required a reduction in the reactive surface area of calcite

554 with time, which is consistent with a passivation mechanism (formation of gypsum

555 coatings on calcite surfaces).

556

557 Acknowledgements

558

559 This work was funded by projects CTM2007-66724-C02-01/TECNO and CGL2010-

560 20984-C02-01 from the Spanish Government. FGO was supported by a JAE-Predoc

561 grant under the Program "Junta para la Ampliación de Estudios". We would like to

562 thank Natàlia Moreno and Rafel Bartrolí (IDAEA), Josep Elvira (IJA) and Maite

563 Romero (SCT-Barcelona University) for analytical assistance and Alejandro Blanco

564 Romero (IDAEA) for technical support. Cosmin Dobrea and Adrian Sima (NILPRP)

565 are thanked for $\mathrm{mCT}$ assistance. Carles Ayora (IDAEA) is thanked for thorough

566 discussions.

567 


\section{References}

569 [1] D.W. Blowes, C.J. Ptacek, J.L. Jambor, C.G. Weisner, The geochemistry of acid

570 mine drainage, in: Treatise on Geochemistry, Volume 9. Editor: Barbara Sherwood 571 Lollar (Ed) 2003, pp. 149-204.

572 [2] G.E. Brown, G. Calas, Environmental mineralogy - Understanding element 573 behavior in ecosystems, Comptes Rendus Geosci. 343 (2011) 90-112.

574 [3] P.L. Younger, The longevity of minewater pollution: a basis for decision575 making, Sci. Total Environ. 194/195 (1997) 457-466.

576 [4] V.P. Evangelou, Y.L. Zhang, A Review: Pyrite Oxidation Mechanisms and Acid

577 Mine Drainage Prevention, Critical Reviews in Environ. Sci. Technol. 25 (1995) 141578199.

579 [5] D.B. Johnson, Chemical and microbiological characteristics of mineral spoils 580 and drainage waters at abandoned coal and metal mines, Water Air Soil Pollut. 3 (2003) $581 \quad 47-66$.

582 [6] H. Cheng, Y. Hu, J. Luo, B. Xu, J. Zhao, Geochemical processes controlling fate 583 and transport of arsenic in acid mine drainage (AMD) and natural systems, J. Hazard. 584 Mater. 165 (2009) 13-26.

585 [7] C.A. Cravotta III, Dissolved metals and associated constituents in abandoned 586 coal-mine discharges, Pennsylvania, USA. Part 1: Constituent quantities and 587 correlations, Appl. Geochemistry 23 (2008) 166-202.

588 [8] M.P. Asta, C. Ayora, G. Román-Ross, J. Cama, P. Acero, A.G. Gault, J.M. 589 Charnock, F. Bardelli, Natural attenuation of arsenic in the Tinto Santa Rosa acid 590 stream (Iberian Pyritic Belt, SW Spain): The role of iron precipitates, Chem. Geol. 271 $591 \quad$ (2010) 1-12. 
592 [9] P.C. Singer, W. Stumm, Acid mine drainage: The rate limiting step, Science 167 593 (1970) 1121-1123.

594 [10] J.M. Bigham, U. Schwertmann, T. S.J., R.L. Winland, M. Wolf, Schwermannite 595 and the chemical modelling of iron in acid sulphate waters, Geochim. Cosmochim. Acta $596 \quad 60(1996) 2111-2121$.

597 [11] D.R. Turner, D. McCoy, Anoxic alkaline drain treatment system a low cost acid 598 mine drainage treatment alternative. In: Proc. Nat. Symp. Surface Mining Hydrology 599 Sedimentology and Reclamation, Lexington, KY, 1990, pp. 73-75.

600 [12] R.S. Hedin, G.R. Watzlaf, R.W. Nairn, Treatment of Acid Mine Drainage with 601 Limestone, J. Environ. Manage. 23 (1994) 1338-1345.

602 [13] B. Gazea, K. Adam, A. Kontopoulos, A review of passive systems for the 603 treatment of acid mine drainage, Miner. Eng. 9 (1996) 23-42.

604 [14] C.A. Cravotta III, M.K. Trahan, Limestone drains to increase $\mathrm{pH}$ and remove 605 dissolved metals from acidic mine drainage, Appl. Geochemistry 14 (1999) 581-606.

606 [15] C.A. Cravotta III, Size and performance of anoxic limestone drains to neutralize 607 acidic mine drainage, J. Environ. Qual. 32 (2003) 1277-89.

608 [16] B.J. Watten, P.L. Sibrell, M.F. Schwartz, Acid neutralization within limestone 609 sand reactors receiving coal mine drainage, Environ. Pollut. 137 (2005) 295-304.

610 [17] B.J. Watten, P.C. Lee, P.L.Sibrell, M.B. Timmons,. Effect of temperature, 611 hydraulic residence time and elevated $\mathrm{PCO} 2$ on acid neutralization within a pulsed 612 limestone bed reactor, Water Res. 41 (2007) 1207-1214.

613 [18] F.H. Pearson, A.J. McDonnell, Use of crushed limestone to neutralize acid 614 wastes, J. Environ. Eng. Div. 101 (1975) 139-158.

615 [19] L. Santoro, G. Valpolicelli, V.Caprio, Limestone neutralization of acid waters in 616 the presence of surface precipitates, Water Res. 21 (1987) 641-647. 
617 [20] J. Hammarstrom, Characterization of limestone reacted with acid-mine drainage

618 in a pulsed limestone bed treatment system at the Friendship Hill National Historical

619 Site, Pennsylvania, USA, Appl. Geochemistry 18 (2003) 1705-1721.

620 [21] G.R. Watzlaf, K.T. Schroeder, R.L.P. Kleinmann, C.L. Kairies, R.W. Nairn,

621 W.B. Street, The Passive Treatment of Coal Mine Drainage, 2004, pp 1-72

622 DOE/NETL-2004/1202. Washington, D.C.: U.S. Department of Energy.

623 [22] S. Santomartino, J. Webb, Estimating the longevity of limestone drains in 624 treating acid mine drainage containing high concentrations of iron, Appl. Geochemistry $62522(2007) 2344-2361$.

626 [23] M.A. Caraballo, T.S. Rotting, J.M. Nieto, C. Ayora, Sequential extraction and 627 DXRD applicability to poorly crystalline Fe- and Al-phase characterization from an 628 acid mine water passive remediation system, Am. Mineral. 94 (2009) 1029-1038.

629 [24] M.A. Caraballo, T.S. Rötting, F. Macías, J.M. Nieto, C. Ayora, Field multi-step 630 limestone and $\mathrm{MgO}$ passive system to treat acid mine drainage with high metal 631 concentrations, Appl. Geochemistry 24 (2009) 2301-2311.

632 [25] J. Booth, Q. Hong, R. Compton, K. Prout, R. Payne, Gypsum Overgrowths 633 Passivate Calcite to Acid Attack, J. Colloid Interface Sci. 192 (1997) 207-14.

634 [26] D.M.C. Huminicki, J.D. Rimstidt, Iron oxyhydroxide coating of pyrite for acid 635 mine drainage control, Appl. Geochemistry 24 (2009) 1626-1634.

636 [27] J.M. Soler, M. Boi, J. Mogollon, J. Cama, C. Ayora, P. Nico, et al., The 637 passivation of calcite by acid mine water. Column experiments with ferric sulfate and 638 ferric chloride solutions at pH 2, Appl. Geochemistry 23 (2008) 3579-3588.

639 [28] D.K. Nordstrom, C.N. Alpers, C.J. Ptacek, D.W. Blowes, Negative pH and 640 Extremely Acidic Mine Waters from Iron Mountain, California, Environ. Sci. Technol. $64134(2000) 254-258$. 
642 [29] C.I. Steefel, CrunchFlow Software for Modeling Multicomponent Reactive Flow 643 and Transport. User’s Manual. 2009 Lawrence Berkeley National Laboratory, Berkeley 644 (USA), 91.

645 [30] D.L. Parkhurst, User guide to PHREEQC - a computer program for speciation, 646 reaction-path, advective-transport, and inverse geochemical calculations, 1995 US 647 Geological Survey Water Resources Investigation Report pp. 95-4227, Lakewood, 648 Colorado, 143.

649 [31] J.D. Allison, D.S. Brown, K. Novo-Gradac, MINTEQA2/PRODEF2, A 650 Geochemical Assessment Model for Environmental Systems: Version 3.0 User's 651 Manual, 1991. EPA/600/3-91/021 Athens, GA, 30605: EPA (USA).

652 [32] M. Dierick, B. Masschaele, L. Van Hoorebeke, Octopus, a fast and user-friendly 653 tomographic reconstruction package developed in LabView. Meas. Sci. Technol. 15 654 (2004) 1366-1370.

655 [33] Volume Graphics VGStudio MAX, http://www.volumegraphics.com, 656 Heidelberg, Germany.

657 [34] C.A. Schneider, W.S. Rasband, K.W. Eliceiri, NIH Image to ImageJ: 25 years of 658 image analysis, Nat. Methods. 9 (2012) 671-675.

659 [35] Amira 5.2 3D visualization software, Visage Imaging, Berlin, Germany 660 http://www.amira.com.

661 [36] C.I. Steefel, A.C. Lasaga, A coupled model of multiple chemical species and 662 kinetic precipitation/dissolution reactions with application to reactive flow in single 663 phase hydrothermal systems. Am. J. Sci. 294 (1994), 529-592.

664 [37] M.A. Caraballo, F. Macias, J.M. Nieto, J. Castillo, D. Quispe, C. Ayora, 665 Hydrochemical performance and mineralogical evolution of a dispersed alkaline 
Offeddu F.G. et al. (2014) Limestone passive treatment

666 substrate (DAS) remediating the highly polluted acid mine drainage in the full-scale

667 passive treatment of Mina Esperanza (SW Spain), Am. Mineral. 96 (2011) 1270-1277.

668 [38] T.S. Rötting, R.C. Thomas, C. Ayora, J. Carrera, Passive treatment of acid mine

669 drainage with high metal concentrations using dispersed alkaline substrate., J. Environ.

670 Qual. 37 (2005) 1741-51.

671 [39] E.L. Sjöberg, D.T Rickard, Temperature dependence of calcite dissolution 672 kinetics between 1 and $62^{\circ} \mathrm{C}$ at $\mathrm{pH} 2.7$ to 8.4 in aqueous solutions. Geochim. 673 Cosmochim. Acta 48 (1984), 485-493.

674 [40] T.J. Wolery, K.J. Jackson, W.L. Bourcier, C.J. Bruton, B.E. Viani, K.G. Knauss, 675 J.M. Delany, Current status of the EQ3/6 software package for geochemical modeling. 676 In: Melchior, C., Bassett, R.L. (Eds.), Chem. Model. Aqueous Systems II. ACS Symp. 677 Series $416(1990)$ 104-116.

678 [41] J.L. Palandri, Y.K. Kharaka, A Compilation of Rate Parameters of Water679 Mineral Interaction Kinetics for Application to Geochemical Modeling. U.S. Geological 680 Survey Water-Resources Investigations Report 04-1068 (2004).

681

682 
Offeddu F.G. et al. (2014) Limestone passive treatment

\section{Figure captions}

684

685 Figure 1. (a) Scheme of the experimental setup. (b) Scheme of a mixed long column 686 (diameter $2.6 \mathrm{~cm}$, length $6 \mathrm{~cm}$ ). In addition to the layers of glass beads at the bottom 687 and top, glass beads were mixed with the calcite grains (67 wt\% and $33 \mathrm{wt} \%$, 688 respectively). (c) Photograph of an assembled column $(1.2 \mathrm{~cm} \times 1.2 \mathrm{~cm})$.

690 Figure 2. (a) Variation of output $\mathrm{pH}$ and output concentrations of $\mathrm{Al}, \mathrm{Ca}$ and $\mathrm{SO}_{4}$ with

691 time in experiment 16 (Table 1). (b) Variation of output $\mathrm{pH}$ and output concentrations 692 of $\mathrm{Fe}, \mathrm{Ca}$ and $\mathrm{SO}_{4}$ with time in experiment $3 \mathrm{CAL}$.

693

694 Figure 3. (a) SEM image showing gypsum crystals that coat a calcite grain (not visible 695 under the precipitates) in experiment 16 (Table 1). The surrounding material is Al696 hydroxide precipitate (gibbsite) which was identified by X-ray microdiffraction (a and 697 e). (b) SEM image that shows a calcite grain on the right, a gypsum coating and Fe698 oxyhydroxide (goethite) in a representative passivated column (1 CAL, 8.7 $\times 10^{-3} \mathrm{~mol} \mathrm{~L}^{-1}$ $699 \mathrm{Fe}(\mathrm{III}), 1.8 \times 10^{-2} \mathrm{~mol} \mathrm{~L}^{-1} \mathrm{SO}_{4}{ }^{2-}$ and $\mathrm{pH}$ 2). (c) and (d) Optical micrographs of the 700 samples. (e) and (f) $\mathrm{mXRD}$ profiles indicating the presence of gibbsite, goethite and 701 calcite.

702

703 Figure 4. Plots of passivation time normalized to residence time (tau) vs. input 704 concentration of $\mathrm{SO}_{4}$ are shown in (a, column experiments with $\mathrm{Fe}_{2}\left(\mathrm{SO}_{4}\right)_{3}$ input 705 solutions) and (c, column experiments with $\mathrm{Al}_{2}\left(\mathrm{SO}_{4}\right)_{3}$ input solution). Plots of metal 706 retention vs. input $\mathrm{SO}_{4}$ concentration are shown in (b) and (d). The arrows in (a) and (b) 707 indicate columns that underwent clogging. Arrows in (c) and (d) represent experiment 
runs with input solution at $\mathrm{pH}$ 3. Different symbols represent different column sizes

709 (length and diameter). Flow rate in all experiments is $1.0 \times 10^{-3} \mathrm{~L} \mathrm{~m}^{-2} \mathrm{~s}^{-1}$.

710

711 Figure 5. mCT image of Column $\mathrm{H}$ after passivation that shows calcite grains (Cal)

712 coated by gypsum (Gp, dark gray layer surrounding calcite surfaces). Precipitation of

713 goethite (Gth, whitish phases) happens between grains and becomes the main

714 responsible for decrease in porosity. Dark areas are pores.

715

716 Figure 6. Four mCT images of the same section (see arrow) of Column H (Table 2)

717 during the experiment: $\mathrm{d} 0$, before reaction; $\mathrm{d} 4$, $\mathrm{d} 8$ and $\mathrm{d} 12$, after 4,8 and 12 days

718 (passivation at $\approx 300 \mathrm{~h}$ ). As the grains were not cemented, relative positions change

719 slightly in the 4 images.

720

721 Figure 7. (a) mCT images of four sections from Column $\mathrm{H}$ after passivation $(\approx 300 \mathrm{~h})$

722 that show the distribution of precipitates along the column. The solid line in the top 723 section separates a reacted from a non-reacted zone. Glass beads are visible at the

724 bottom and top sections of the column. (b) Scheme showing the location of the sections 725 along the column.

726

727 Figure 8. Porosity variation with time along column H. The arrow indicates the flux 728 direction. $\mathrm{d} 0, \mathrm{~d} 4, \mathrm{~d} 8$ and $\mathrm{d} 12$ stand for measurements at $0,4,8$ and 12 days, 729 respectively. Porosity decreases from an initial value of $48 \pm 2 \%$ to $31 \pm 2 \%$.

730

731 Figure 9. Contributions of goethite (a) and gypsum (b) to porosity variation in column

$732 \mathrm{H}$. They were calculated by segmentation of the mCT images taken after 4,8 and 12 
733 days. After passivation, the average gypsum content is about $3 \%$ and that of goethite is

734 ca. $14 \%$. Consistent with the formation of preferential flow paths, the amount of 735 precipitates decreases from the bottom (inlet) to the top (outlet).

736

737 Figure 10. Variation of the output concentrations of $\mathrm{Ca}, \mathrm{SO}_{4}$ and $\mathrm{Fe}$ and $\mathrm{pH}$ with time 738 in experiment LCAL 1mix.

739

740 Figure 11. mCT images of four sections from column LCAL1-mix after passivation.

741 The distribution of precipitates is homogeneous with no preferential flow paths. The 742 whitish particles between grains and beads are goethite. The final mean porosity is $16 \pm$ $743 \quad 3 \%$.

745 Figure 12. Porosity variation along Column LCAL-1. The upper line is the distribution 746 of porosity along the column $(39 \pm 3 \%)$ before the experiment start. The lower line is 747 the final porosity after passivation $(16 \pm 3 \%$, passivation time was $\sim 50$ days). The arrow 748 indicates the flux direction. The homogenous distribution of porosity along the column 749 suggests that no preferential flow paths were formed, yielding a constant porosity 750 decrease.

752 Figure 13. Experimental and modeling results (output concentrations vs. time) from 753 column $\mathrm{H}$. 
Offeddu F.G. et al. (2014) Limestone passive treatment

\section{Table heads}

757

758 Table 1 Experimental conditions of the aluminum column experiments.

759

760 Table 2 Experimental conditions of the iron column experiments.

761

762 Table 3 Parameters used in the reactive transport calculations.

763

764 Table 4 Equilibrium constants for the mineral reactions considered in the calculations

765

766 Table 5 Equilibria in solution considered in the calculations.

767

768 Table 6 Kinetic parameters in the mineral dissolution/precipitation rate laws $\left(25^{\circ} \mathrm{C}\right)$

769 (Palandri and Kharaka, 2004).

770 

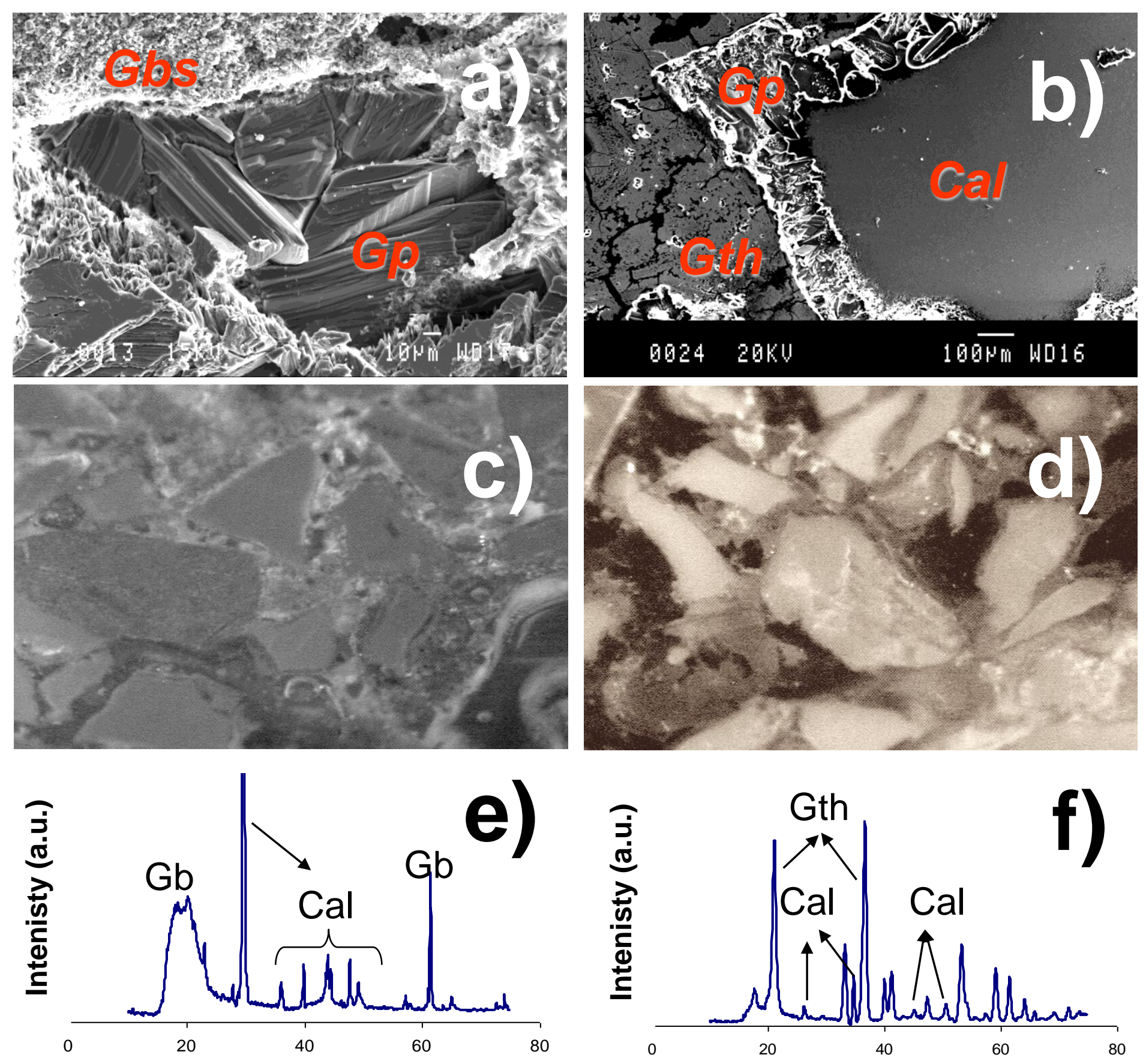
Figure 5

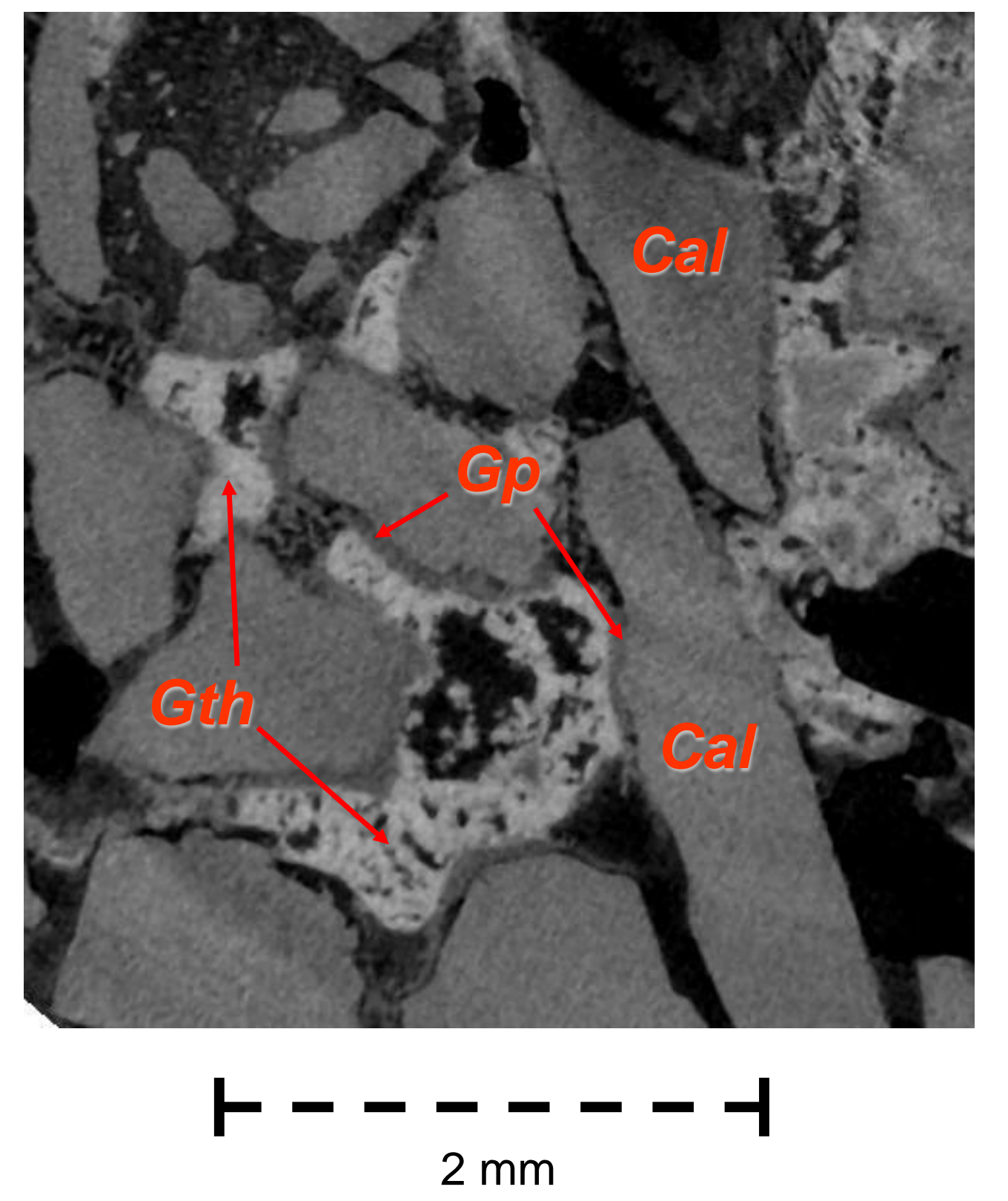

$$
\text { ト - }-\frac{-}{2 \mathrm{~mm}}-\boldsymbol{-}
$$

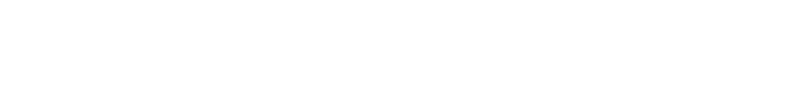



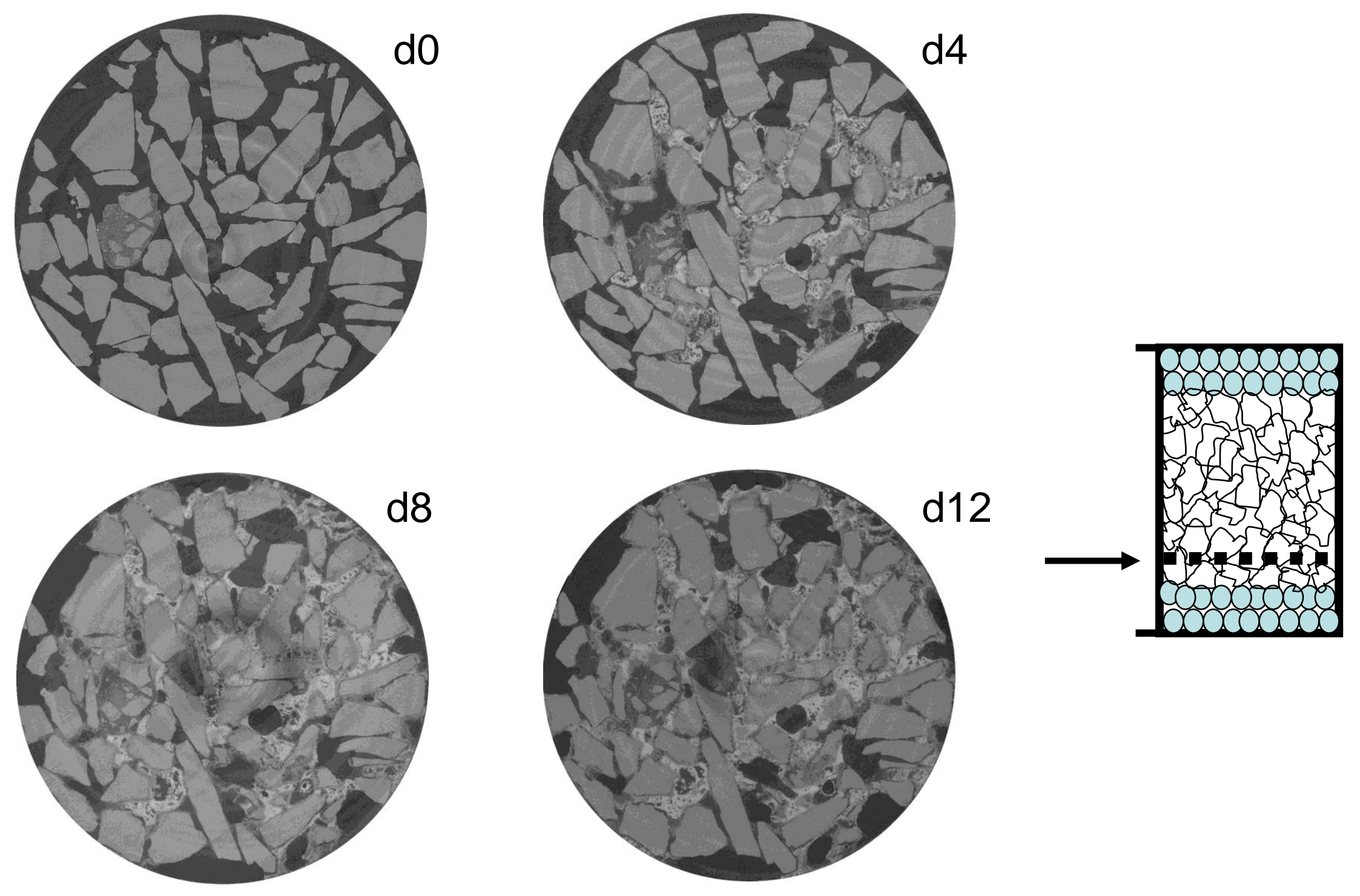

$1--------1$

Diameter $1.2 \mathrm{~cm}$ 
a)

B (bottom, inlet)

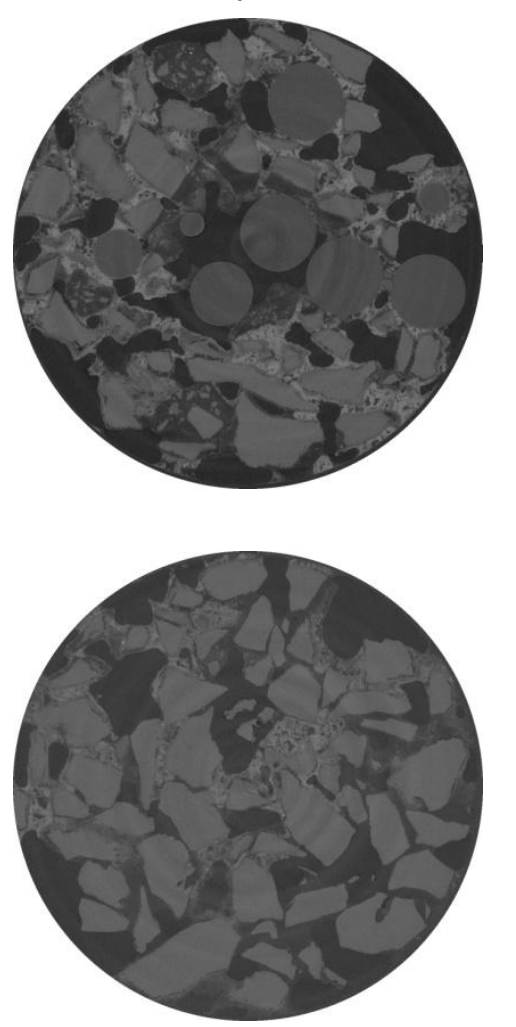

UM (upper middle)

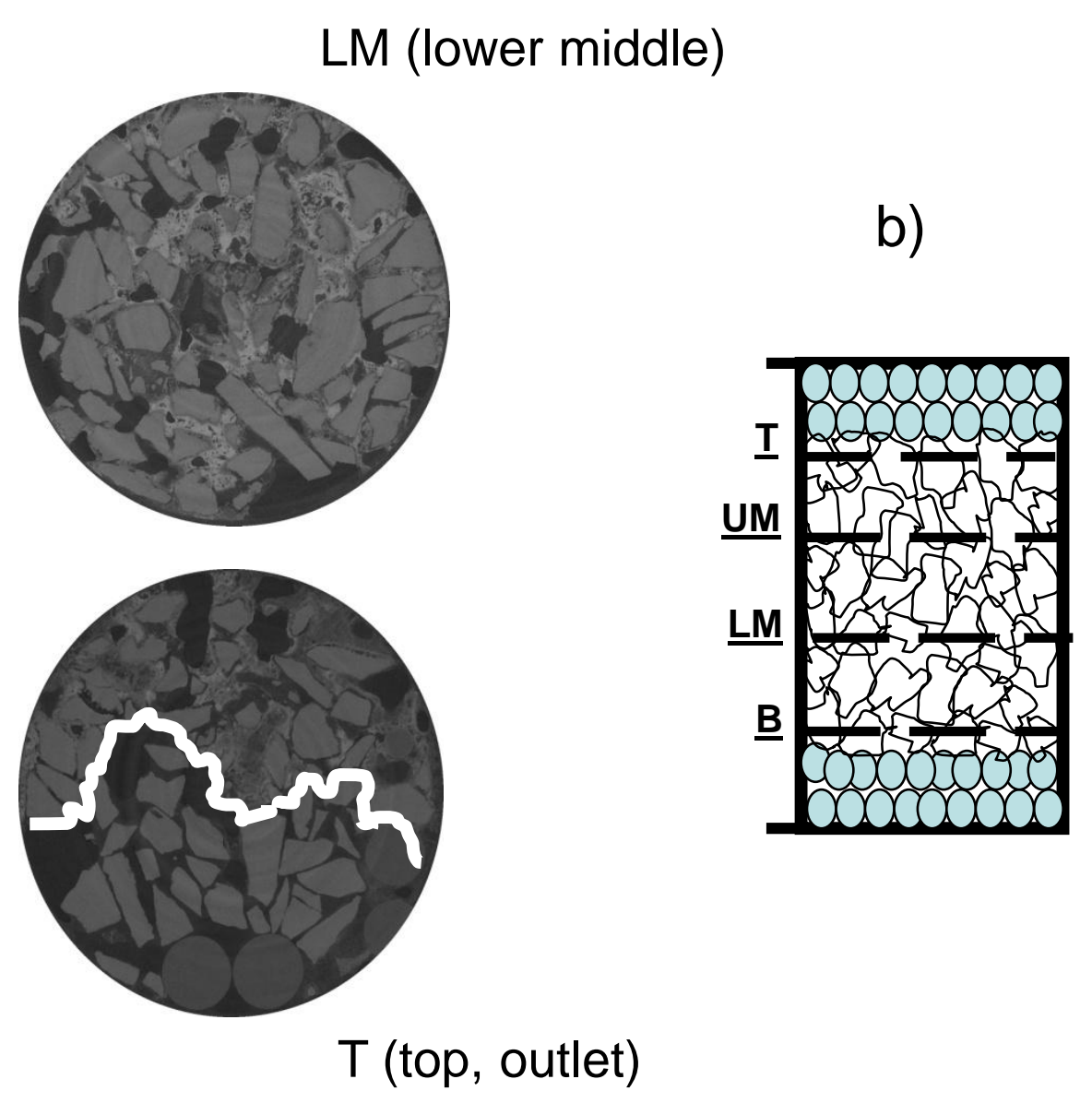

1 - - - -

Diameter $1.2 \mathrm{~cm}$

$\mathrm{T}$ (top, outlet) 


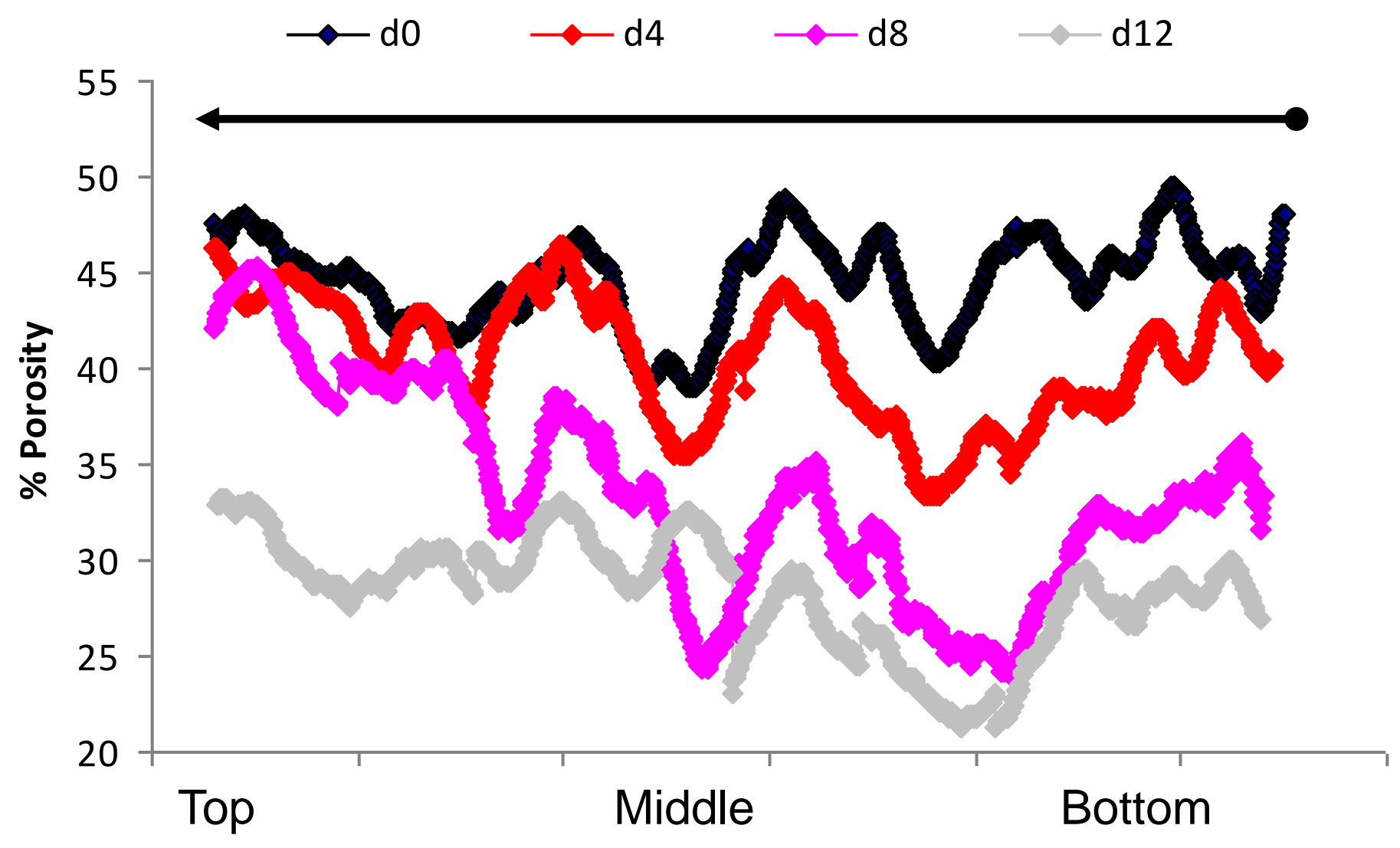




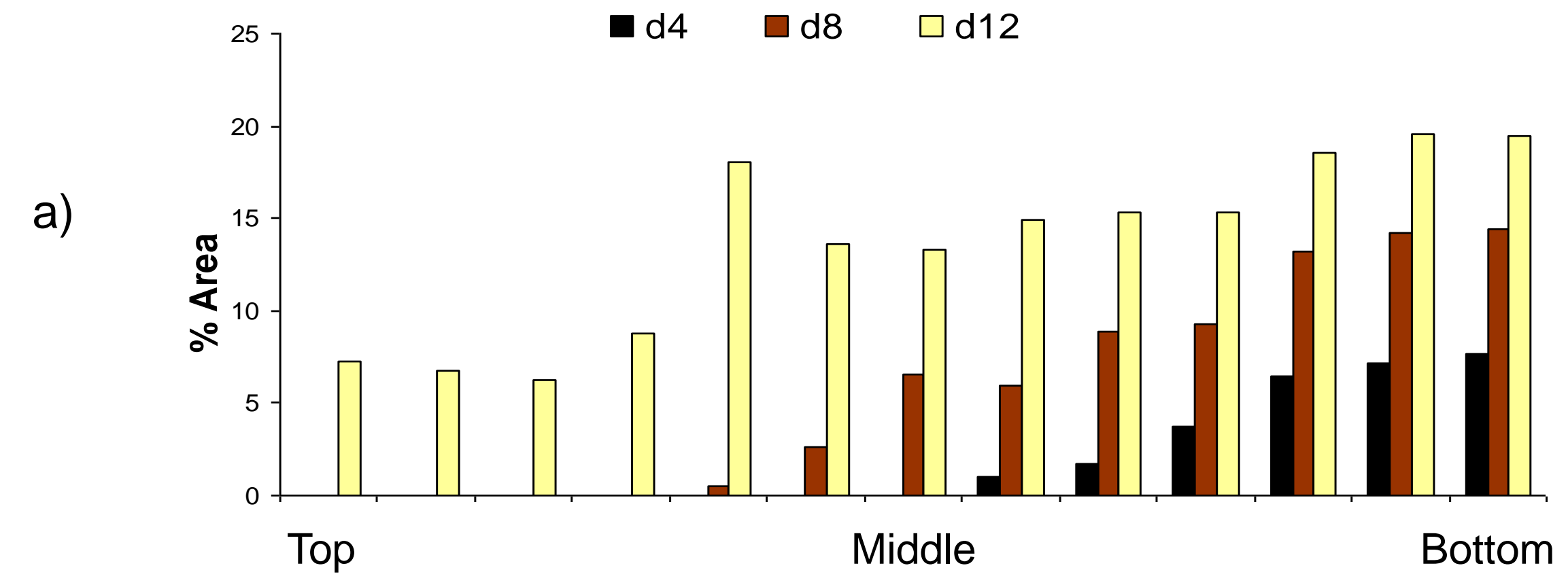

b)

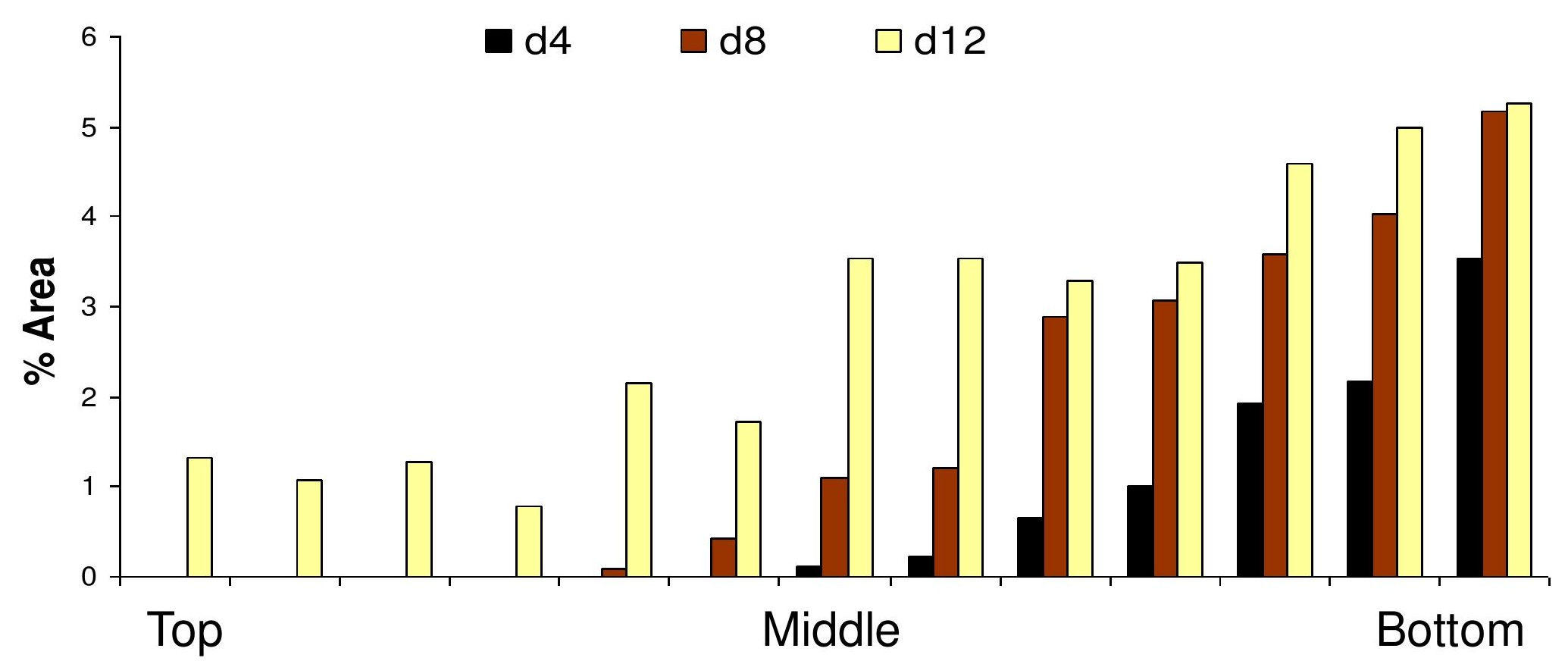




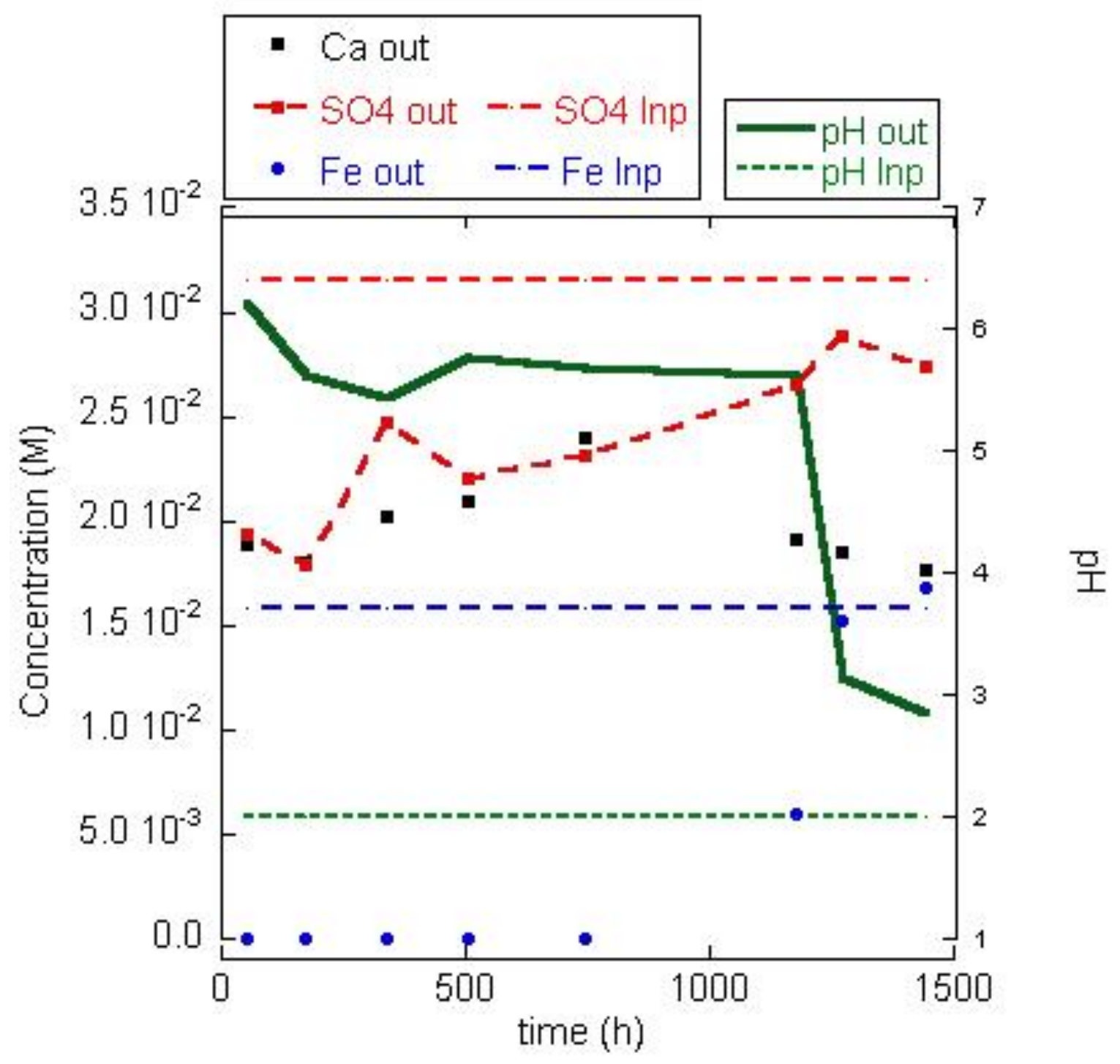


B (inlet, bottom)
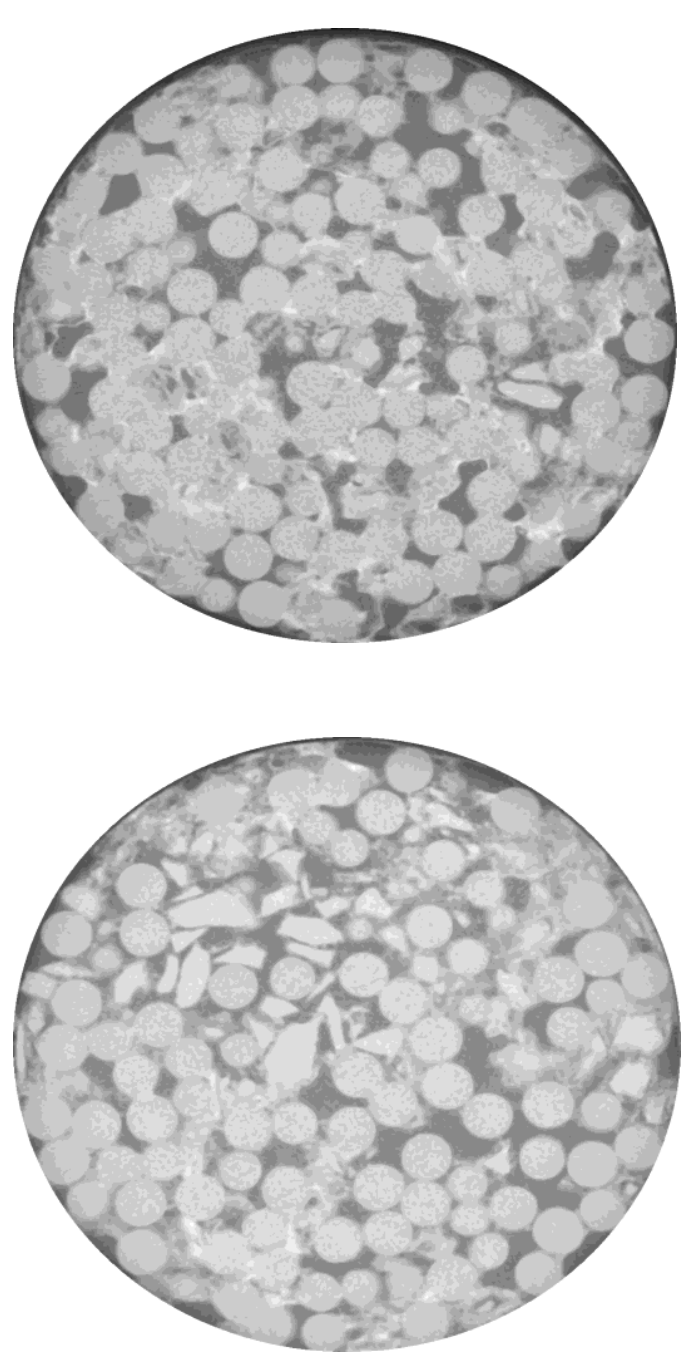

UM (upper middle)
LM (lower middle)
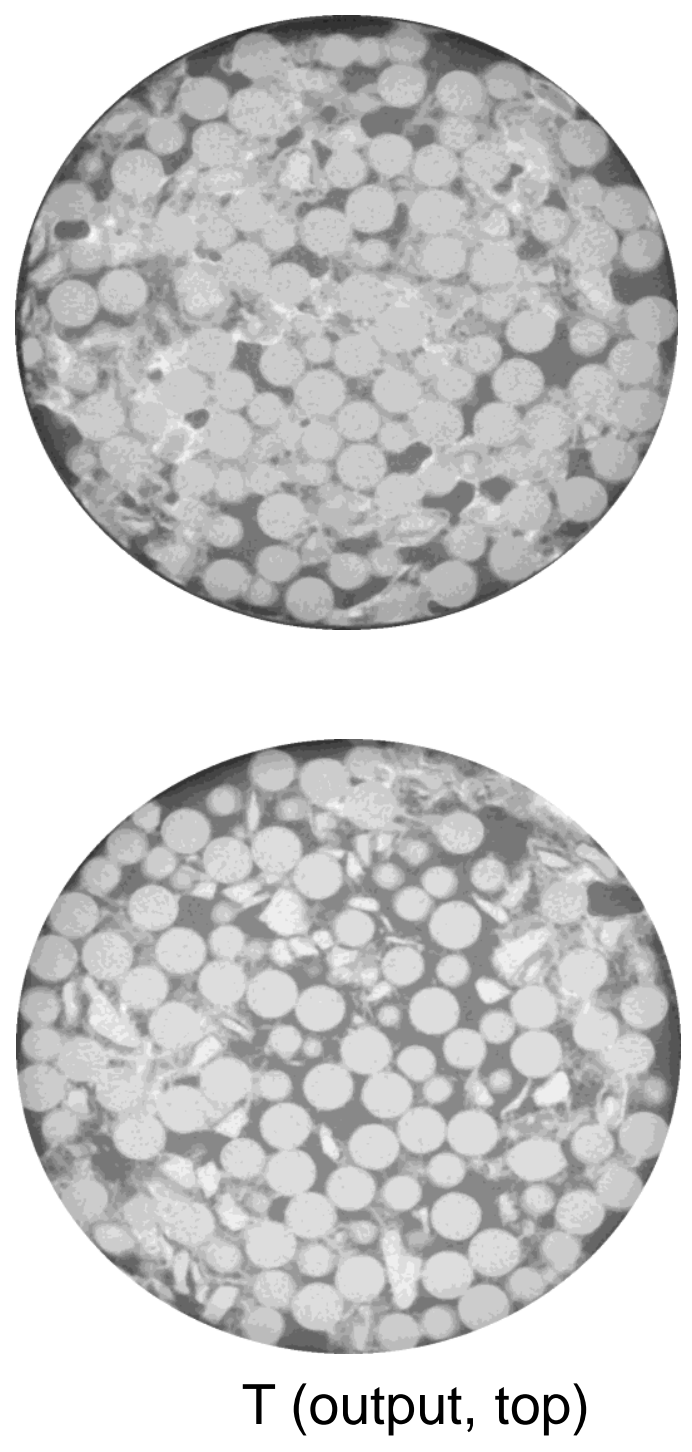

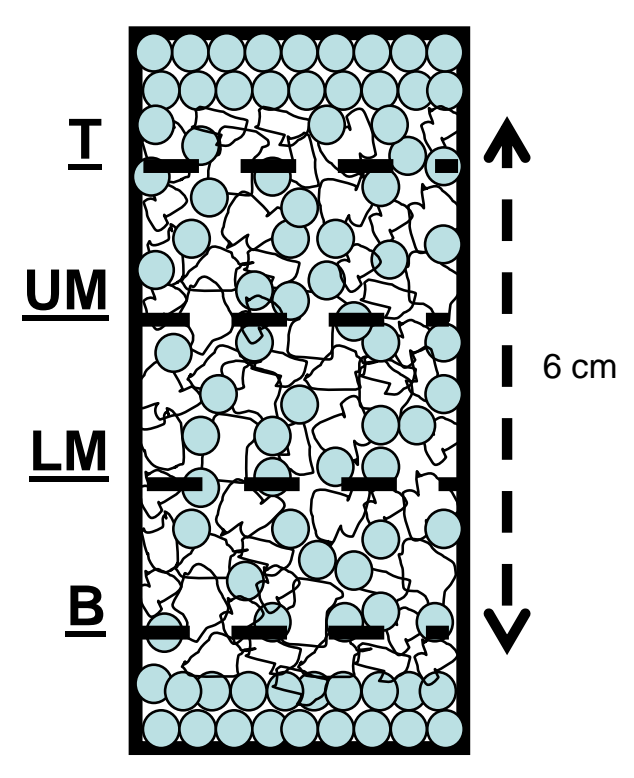




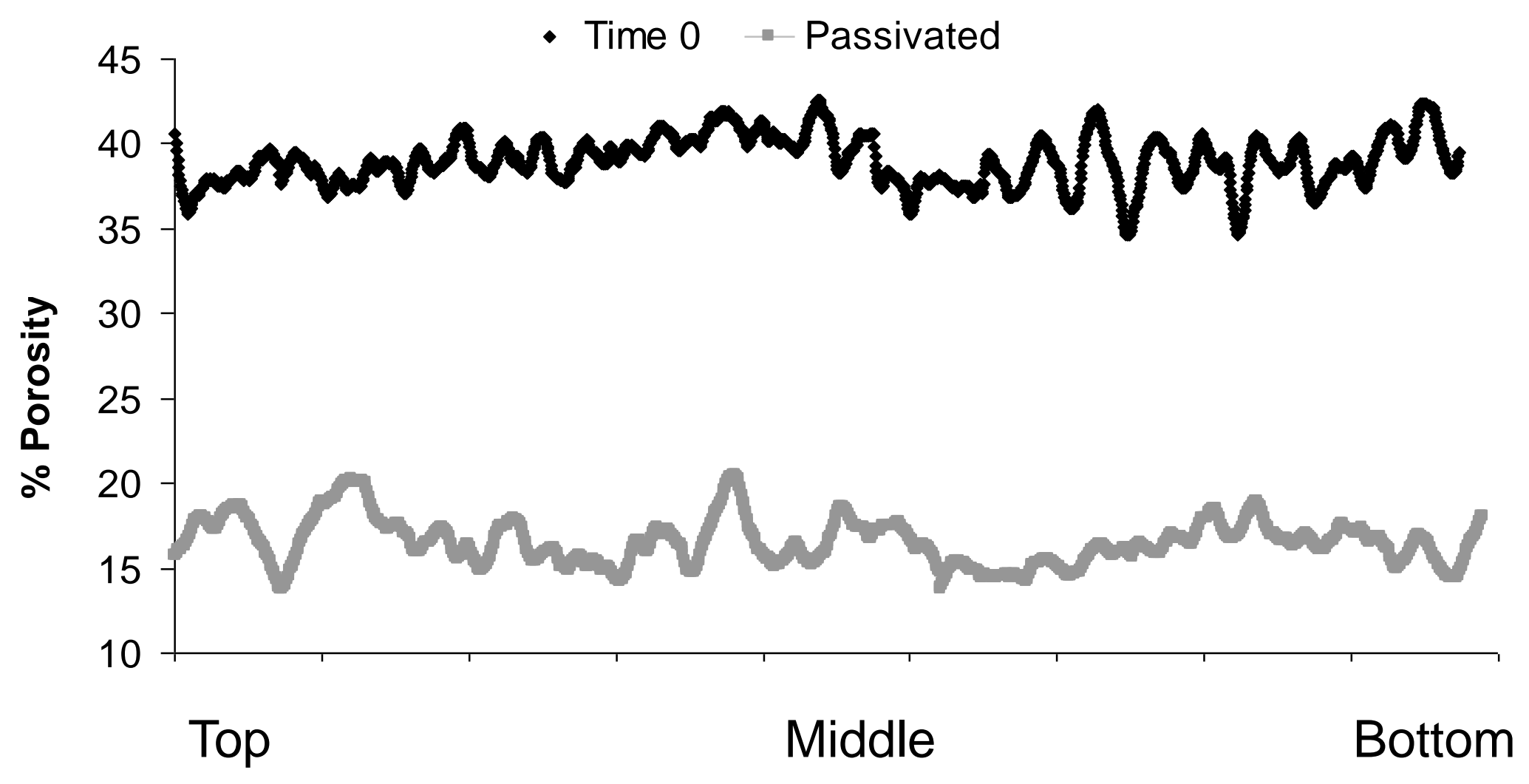




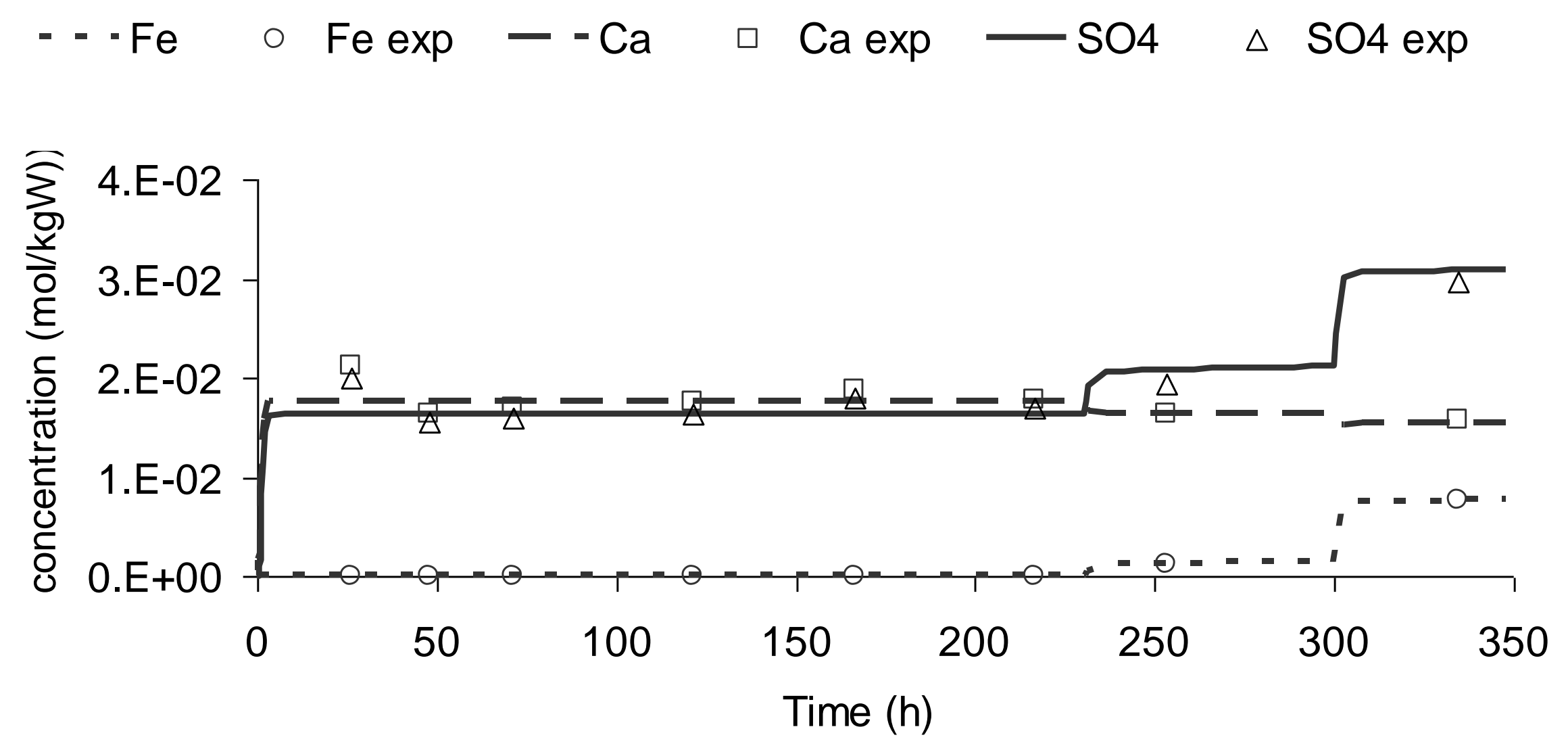




\begin{tabular}{cccccccccc}
\hline column & $\begin{array}{c}\text { weight } \\
\text { limestone } \\
(\mathrm{g})\end{array}$ & $\begin{array}{c}\mathrm{Al} \\
(\mathrm{M})\end{array}$ & $\begin{array}{c}\mathrm{SO}_{4} \\
(\mathrm{M})\end{array}$ & $\begin{array}{c}\text { column } \\
\text { length } \\
(\mathrm{cm})\end{array}$ & $\begin{array}{c}\text { column } \\
\text { diameter } \\
(\mathrm{cm})\end{array}$ & $\begin{array}{c}\text { porosity } \\
(\%)\end{array}$ & $\begin{array}{c}\mathrm{t}_{\text {pass }} / \mathrm{tau} \\
\text { time } \\
(\mathrm{h})\end{array}$ & $\begin{array}{c}\mathrm{mg} \mathrm{Al} / \\
\mathrm{g} \text { calcite }\end{array}$ \\
\hline 16 & 19.8 & $3.61 \mathrm{E}-02$ & $5.92 \mathrm{E}-02$ & 2.5 & 2.6 & 45 & 67 & 210 & 20 \\
11 & 18.8 & $1.80 \mathrm{E}-02$ & $3.19 \mathrm{E}-02$ & 2.4 & 2.6 & 46 & 180 & 547 & 27 \\
10 & 19.7 & $9.27 \mathrm{E}-03$ & $1.89 \mathrm{E}-02$ & 2.7 & 2.6 & 49 & 44 & 162 & 4 \\
4 & 18.5 & $7.20 \mathrm{E}-03$ & $1.58 \mathrm{E}-02$ & 2.6 & 2.6 & 51 & 323 & 1183 & 24 \\
2 & 17.0 & $7.20 \mathrm{E}-03$ & $1.58 \mathrm{E}-02$ & 2.6 & 2.6 & 55 & 291 & 1147 & 25 \\
9 & 14.5 & $3.60 \mathrm{E}-03$ & $1.04 \mathrm{E}-02$ & 2.1 & 2.6 & 52 & 623 & 1893 & 24 \\
C & 1.8 & $3.60 \mathrm{E}-03$ & $1.04 \mathrm{E}-02$ & 2.6 & 2.6 & 49 & 396 & 1411 & 14 \\
A & 1.6 & $9.27 \mathrm{E}-03$ & $1.89 \mathrm{E}-02$ & 1.2 & 1.2 & 57 & 152 & 291 & 18 \\
M & 1.6 & $7.20 \mathrm{E}-03$ & $1.58 \mathrm{E}-02$ & 1.1 & 1.2 & 51 & 178 & 280 & 13 \\
N & 1.8 & $7.20 \mathrm{E}-03$ & $1.58 \mathrm{E}-02$ & 1.2 & 1.2 & 50 & 168 & 280 & 12 \\
$6 \mathrm{CAL}$ & 15.0 & $1.80 \mathrm{E}-02$ & $3.19 \mathrm{E}-02$ & 6 & 2.6 & 40 & 73 & 501 & 31 \\
$7 \mathrm{CAL}$ & 14.0 & $3.60 \mathrm{E}-03$ & $1.04 \mathrm{E}-02$ & 6 & 2.6 & 40 & 460 & 3330 & 44 \\
$8 \mathrm{CAL}$ & 14.1 & $3.60 \mathrm{E}-03$ & $1.04 \mathrm{E}-02$ & 6 & 2.6 & 40 & 418 & 3018 & 40 \\
$9 \mathrm{CAL}$ & 14.0 & $3.60 \mathrm{E}-03$ & $1.04 \mathrm{E}-02$ & 6 & 2.6 & 40 & 444 & 3211 & 42 \\
\hline
\end{tabular}


All column experiments run at $1 \times 10^{-3} \mathrm{~L} \mathrm{~m}^{-2} \mathrm{~s}^{-1}$.

Initial pH is 2 except in 4 and 2 where it is 3.

All column experiments were passivated.

t denote time in hours needed to passivate the column.

tau denotes residence time calculated as $\mathrm{V} / \mathrm{Q}$.

t/tau denotes passivation time normalized with respect to residence time.

$\mathrm{mg} \mathrm{Al} / \mathrm{g}$ limestone denotes amount of aluminum retained by limestone. 
Table 2

\begin{tabular}{|c|c|c|c|c|c|c|c|c|c|c|c|}
\hline column & $\begin{array}{l}\text { weight } \\
\text { limestone } \\
(\mathrm{g})\end{array}$ & $\begin{array}{l}\mathrm{Fe} \\
(\mathrm{M})\end{array}$ & $\begin{array}{l}\mathrm{SO}_{4} \\
\text { (M) }\end{array}$ & $\begin{array}{c}\text { column } \\
\text { length } \\
(\mathrm{cm})\end{array}$ & $\begin{array}{l}\text { column } \\
\text { diameter } \\
(\mathrm{cm})\end{array}$ & $\begin{array}{c}\text { porosity } \\
(\%)\end{array}$ & $\begin{array}{l}\text { flow rate } \\
\left(\mathrm{L} / \mathrm{m}^{2} / \mathrm{s}\right)\end{array}$ & $\mathrm{t}_{\mathrm{pass}} / \mathrm{tau}$ & $\begin{array}{l}\text { time } \\
\text { (h) }\end{array}$ & $\begin{array}{c}\mathrm{mg} \mathrm{Fe} / \mathrm{g} \\
\text { calcite }\end{array}$ & passivated \\
\hline 3 & 16.40 & $2.60 \mathrm{E}-02$ & 4.39E-02 & 2.8 & 2.6 & 59 & $1.0 \mathrm{E}-03$ & 141 & 593 & 101 & YES \\
\hline 8 & 18.47 & $1.34 \mathrm{E}-02$ & $2.51 \mathrm{E}-02$ & 2.5 & 2.6 & 47 & $1.0 \mathrm{E}-03$ & 117 & 331 & 26 & YES \\
\hline 7 & 19.86 & $6.72 \mathrm{E}-03$ & $1.51 \mathrm{E}-02$ & 2.5 & 2.6 & 45 & $1.0 \mathrm{E}-03$ & 263 & 743 & 27 & YES \\
\hline $2 \mathrm{CAL}$ & 13.23 & 8.70E-03 & $1.80 \mathrm{E}-02$ & 1.6 & 2.6 & 43 & $1.0 \mathrm{E}-03$ & 301 & 518 & 36 & YES \\
\hline $3 \mathrm{CAL}$ & 14.65 & 8.70E-03 & $1.80 \mathrm{E}-02$ & 1.7 & 2.6 & 40 & $1.0 \mathrm{E}-03$ & 972 & 1676 & 107 & YES \\
\hline $4 \mathrm{CAL}$ & 14.63 & $3.49 \mathrm{E}-03$ & $1.02 \mathrm{E}-02$ & 1.8 & 2.6 & 44 & $1.0 \mathrm{E}-03$ & 2241 & 4438 & 113 & YES \\
\hline $5 \mathrm{CAL}$ & 14.21 & $3.49 \mathrm{E}-03$ & $1.02 \mathrm{E}-02$ & 1.7 & 2.6 & 42 & $1.0 \mathrm{E}-03$ & 2651 & 4774 & 125 & CLOG. \\
\hline $1 \mathrm{~A}$ & 1.71 & $3.49 \mathrm{E}-03$ & $1.02 \mathrm{E}-02$ & 1.2 & 1.2 & 54 & $1.0 \mathrm{E}-03$ & 1273 & 2201 & 105 & CLOG. \\
\hline $2 \mathrm{~A}$ & 1.56 & $3.49 \mathrm{E}-03$ & $1.02 \mathrm{E}-02$ & 1.2 & 1.2 & 58 & $1.0 \mathrm{E}-03$ & 744 & 1385 & 72 & YES \\
\hline $7 \mathrm{~A}$ & 1.67 & $3.49 \mathrm{E}-03$ & $1.02 \mathrm{E}-02$ & 1.1 & 1.2 & 50 & $6.0 \mathrm{E}-04$ & 1827 & 1185 & 33 & CLOG. \\
\hline $\mathrm{H}$ & 1.86 & $1.74 \mathrm{E}-02$ & $3.11 \mathrm{E}-02$ & 1.2 & 1.2 & 49 & $1.0 \mathrm{E}-03$ & 188 & 300 & 66 & YES \\
\hline D & 1.76 & $1.34 \mathrm{E}-02$ & $2.51 \mathrm{E}-02$ & 1.2 & 1.2 & 52 & $1.0 \mathrm{E}-03$ & 239 & 402 & 72 & YES \\
\hline E & 1.60 & $1.34 \mathrm{E}-02$ & $2.51 \mathrm{E}-02$ & 1.1 & 1.2 & 53 & $1.0 \mathrm{E}-03$ & 231 & 359 & 71 & YES \\
\hline $1 \mathrm{CAL}$ & 1.46 & 8.70E-03 & $1.80 \mathrm{E}-02$ & 1.2 & 1.2 & 60 & $1.0 \mathrm{E}-03$ & 1021 & 1990 & 278 & CLOG. \\
\hline $\mathrm{F}$ & 2.21 & $1.74 \mathrm{E}-02$ & $3.11 \mathrm{E}-02$ & 1.3 & 1.2 & 45 & $6.0 \mathrm{E}-04$ & 132 & 360 & 38 & YES \\
\hline B & 1.68 & $1.34 \mathrm{E}-02$ & $2.51 \mathrm{E}-02$ & 1.1 & 1.2 & 50 & $6.0 \mathrm{E}-04$ & 434 & 1127 & 121 & CLOG. \\
\hline $\mathrm{B}$ bis & 1.61 & $1.34 \mathrm{E}-02$ & $2.51 \mathrm{E}-02$ & 1.2 & 1.2 & 56 & $6.0 \mathrm{E}-04$ & 355 & 1129 & 126 & YES \\
\hline $\begin{array}{l}\text { LCAL1 } \\
\text { mix }\end{array}$ & 15.00 & $1.74 \mathrm{E}-02$ & $3.11 \mathrm{E}-02$ & 6 & 2.6 & 42 & $1.0 \mathrm{E}-03$ & 199 & 1269 & 158 & YES \\
\hline $\begin{array}{l}\text { LCAL2 } \\
\text { mix }\end{array}$ & 15.00 & $1.74 \mathrm{E}-02$ & $3.11 \mathrm{E}-02$ & 6 & 2.6 & 41 & $1.0 \mathrm{E}-03$ & 205 & 1270 & 158 & YES \\
\hline
\end{tabular}


Initial $\mathrm{pH}=2$

t denote time in hours needed to passivate the column.

tau denotes residence time calculated as $\mathrm{V} / \mathrm{Q}$.

t/tau denotes passivation time normalized with respect to residence time.

"mix" indicates column filled with calcite and glass beads $(\sim 1 / 3$ and $\sim 2 / 3$ in weight respectively).

$\mathrm{mg} \mathrm{Fe} / \mathrm{g}$ limestone denotes amount of iron retained by limestone. 


\begin{tabular}{|c|c|c|}
\hline minerals & $\begin{array}{l}\text { reactive surface area } \\
(\mathrm{m} 2 \mathrm{mineral} / \mathrm{m} 3 \text { rock })\end{array}$ & $\begin{array}{c}\text { vol. } \\
\text { fraction }\end{array}$ \\
\hline calcite & 20 & 0.506 \\
\hline gypsum & 10 & 0 \\
\hline goethite & 0.1 & 0 \\
\hline input water & $\begin{array}{c}\text { total conc. } \\
(\mathrm{mol} / \mathrm{kg})\end{array}$ & \\
\hline $\mathrm{Ca}^{2+}$ & $1.00 \mathrm{E}-09$ & \\
\hline $\mathrm{Fe}^{3+}$ & $1.79 \mathrm{E}-02$ & \\
\hline $\mathrm{HCO}_{3}^{-}$ & $1.29 \mathrm{E}-05$ & \\
\hline $\mathrm{SO}_{4}^{2-}$ & $3.42 \mathrm{E}-02$ & \\
\hline $\mathrm{pH}$ & 2.00 & \\
\hline initial rock water & $\begin{array}{l}\text { total conc. } \\
(\mathrm{mol} / \mathrm{kg})\end{array}$ & \\
\hline $\mathrm{Ca}^{2+}$ & $5.32 \mathrm{E}-04$ & \\
\hline $\mathrm{Fe}^{3+}$ & $1.00 \mathrm{E}-19$ & \\
\hline $\mathrm{HCO}_{3}^{-}$ & $1.06 \mathrm{E}-03$ & \\
\hline $\mathrm{SO}_{4}^{2-}$ & $1.00 \mathrm{E}-09$ & \\
\hline $\mathrm{pH}$ & 8.22 & \\
\hline $\begin{array}{c}\text { effective diffusion coefficient } \\
\mathrm{De}\left(\mathrm{m}^{2} / \mathrm{sec}\right)\end{array}$ & $5.00 \mathrm{E}-10$ & \\
\hline dispersivity $\alpha(\mathrm{m})$ & $1.30 \mathrm{E}-03$ & \\
\hline Darcy velocity $\mathrm{m}^{3} / \mathrm{m}^{2} / \mathrm{sec}$ & $1.03 \mathrm{E}-06$ & \\
\hline nodes & 20 & \\
\hline
\end{tabular}




\begin{tabular}{lcl} 
& $\operatorname{logK}_{\mathrm{T}=25^{\circ} \mathrm{C}}$ & \\
\hline Calcite & 1.8480 & $\mathrm{CaCO}_{3}+\mathrm{H}^{+} \leftrightarrow \mathrm{Ca}^{2+}+\mathrm{HCO}_{3}^{-}$ \\
Gypsum & -4.4820 & $\mathrm{CaSO}_{4} \cdot 2 \mathrm{H}_{2} \mathrm{O} \leftrightarrow \mathrm{Ca}^{2+}+\mathrm{SO}_{4}{ }^{2-}+2 \mathrm{H}_{2} \mathrm{O}$ \\
Goethite & 0.5345 & $\mathrm{FeO} \cdot \mathrm{OH}+3 \mathrm{H}^{+} \leftrightarrow \mathrm{Fe}^{3+}+2 \mathrm{H}_{2} \mathrm{O}$ \\
\hline
\end{tabular}




\begin{tabular}{|c|c|}
\hline $\log \mathrm{K}_{25^{\circ} \mathrm{C}}$ & reactions \\
\hline-6.3447 & $\mathrm{CO}_{2(a q)}+\mathrm{H}_{2} \mathrm{O} \leftrightarrow \mathrm{HCO}_{3}^{-}+\mathrm{H}^{+}$ \\
\hline 10.3288 & $\mathrm{CO}_{3}^{2-}+\mathrm{H}_{+} \leftrightarrow \mathrm{HCO}_{3}^{-}$ \\
\hline 7.0017 & $\mathrm{CaCO}_{3}+\mathrm{H}+\leftrightarrow \mathrm{Ca}^{2+}+\mathrm{HCO}_{3}^{-}+\mathrm{H}_{2} \mathrm{O}$ \\
\hline-1.0467 & $\mathrm{CaHCO}_{3}^{-} \leftrightarrow \mathrm{Ca}^{2+}+\mathrm{HCO}_{3}^{-}+\mathrm{H}_{2} \mathrm{O}$ \\
\hline 12.8500 & $\mathrm{CaOH}^{+}+\mathrm{H}^{+} \leftrightarrow \mathrm{Ca}^{2+}+\mathrm{H}_{2} \mathrm{O}$ \\
\hline-2.1110 & $\mathrm{CaSO}_{4(a q)} \leftrightarrow \mathrm{Ca}^{2+}+\mathrm{SO}_{4}{ }^{2-}+\mathrm{H}_{2} \mathrm{O}$ \\
\hline 5.6700 & $\mathrm{Fe}(\mathrm{OH})_{2}^{+}+2 \mathrm{H}^{+} \leftrightarrow \mathrm{Fe}^{3+}+2 \mathrm{H}_{2} \mathrm{O}$ \\
\hline 12.000 & $\mathrm{Fe}(\mathrm{OH})_{3(a q)}+3 \mathrm{H}^{+} \leftrightarrow \mathrm{Fe}^{3+}+3 \mathrm{H}_{2} \mathrm{O}$ \\
\hline 21.6000 & $\mathrm{Fe}(\mathrm{OH})_{4}{ }^{-}(a q)+4 \mathrm{H}^{+} \leftrightarrow \mathrm{Fe}^{3+}+4 \mathrm{H}_{2} \mathrm{O}$ \\
\hline-3.2127 & $\mathrm{Fe}\left(\mathrm{SO}_{4}\right)^{2-} \leftrightarrow \mathrm{Fe}^{3+}+2 \mathrm{SO}_{4}{ }^{2-}$ \\
\hline 2.9500 & $\mathrm{Fe}_{2}(\mathrm{OH})_{2}{ }^{4+}+2 \mathrm{H}^{+} \leftrightarrow 2 \mathrm{Fe}^{3+}+2 \mathrm{H}_{2} \mathrm{O}$ \\
\hline 6.3000 & $\mathrm{Fe}_{3}(\mathrm{OH})_{4}{ }^{5+}+4 \mathrm{H}^{+} \leftrightarrow 3 \mathrm{Fe}^{3+}+4 \mathrm{H}_{2} \mathrm{O}$ \\
\hline 0.6088 & $\mathrm{FeCO}_{3}^{+}+\mathrm{H}^{+} \leftrightarrow \mathrm{Fe}^{3+}+\mathrm{HCO}^{-}$ \\
\hline 9.5000 & $\mathrm{FeOH}^{2+}+\mathrm{H}^{+} \leftrightarrow \mathrm{Fe}^{3+}+\mathrm{H}_{2} \mathrm{O}$ \\
\hline-1.9276 & $\mathrm{FeSO}_{4}^{+} \leftrightarrow \mathrm{Fe}^{3+}+\mathrm{SO}_{4}{ }^{2-}$ \\
\hline 1.0209 & $\mathrm{H}_{2} \mathrm{SO}_{4(a q)} \leftrightarrow \mathrm{SO}_{4}{ }^{2-}+2 \mathrm{H}^{+}$ \\
\hline-1.9791 & $\mathrm{HSO}_{4}^{-} \leftrightarrow \mathrm{SO}_{4}^{2-}+\mathrm{H}^{+}$ \\
\hline
\end{tabular}




\begin{tabular}{ccc} 
mineral & $\mathrm{k}_{\mathrm{m}, 25}\left[\mathrm{~mol} \mathrm{~m}^{-2} \mathrm{~s}^{-1}\right]$ & $\mathrm{n}\left(\mathrm{a}_{\mathrm{H}+}{ }^{\mathrm{n}}\right)$ \\
\hline calcite & $5.01 \mathrm{E}-01$ & 1 \\
& $1.55 \mathrm{E}-06$ & - \\
\hline goethite & $1.15 \mathrm{E}-08$ & - \\
gypsum & $1.62 \mathrm{E}-03$ & - \\
\hline
\end{tabular}

